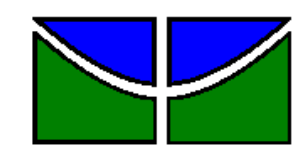

Universidade de Brasília - UnB

Faculdade de Economia, Administração, Contabilidade e Ciência da Informação e Documentação - FACE

Programa de Pós-Graduação Administração - PPGA

MARIA DE FATIMA NERIS RODRIGUES

\title{
A AVALIAÇÃO DO TREINAMENTO GERENCIAL PARA APLICAÇÃO DO PROCESSO DE GESTÃO DE DESEMPENHO
}

Brasília - DF 
MARIA DE FÁTIMA NERIS RODRIGUES

\title{
A AVALIAÇÃO DO TREINAMENTO GERENCIAL PARA APLICAÇÃO DO PROCESSO DE GESTÃO DE DESEMPENHO
}

Monografia apresentada ao Programa de Pós-Graduação em Administração (PPGA) da Faculdade de Economia, Administração, Contabilidade e Ciência da Informação e Documentação (FACE), da Universidade de Brasília, como requisito parcial à obtenção do grau de Especialista em Gestão de Pessoas.

Orientadora: $\operatorname{Prof}^{\mathrm{a}} \mathrm{Dr}^{\mathrm{a}}$ Catarina Cecília Odelius

\author{
Brasília - DF \\ 2008
}




\section{AGRADECIMENTOS}

Á Deus, primeiramente, que na sua bondade infinita, me proporcionou as condições e o potencial necessários para superação dos obstáculos percorridos e para a realização e concretização de mais uma vitória em minha vida.

À minha mãe Liduina e a meu pai Francisco pelo carinho, amor, compreensão, apoio, paciência, incentivo e educação dada aos seus filhos, mesmo com tantas adversidades.

Aos meus irmãos e sobrinhos pelo convívio harmonioso e pela união nos momentos difíceis.

À professora Doutora Catarina Cecília Odelius, minha orientadora, pela compreensão dispensada às minhas dificuldades, pelos conhecimentos transmitidos e por toda dedicação e apoio dado a minha pessoa.

A professora Doutora Maria de Fátima-Bruno, coordenadora do curso, pela interação, disposição e paciência em ajudar-nos, pela dedicação, pelos auxílios sempre relevantes.

Aos meus colegas de curso, em especial, Ana Carolina, Rita de Cássia, Alan e Ariel pela convivência agradável dos momentos compartilhados entre estudos e troca de experiência que foram favoráveis ao alcance dos trabalhos do curso.

Aos meus colegas de trabalho, pela ajuda e pela compreensão nos momentos difíceis que passei e que me apoiaram. 
"Para ter um negócio de sucesso, alguém, algum dia, teve que tomar uma atitude de coragem."

(Peter Drucker)

"O melhor resultado é obtido quando todos no grupo fazem o melhor para si e para o grupo."

John Forbes Nash Jr.

Prêmio Nobel de Economia (1928 - )

"Reunir-se é um começo, permanecer juntos é um progresso, e trabalhar juntos é sucesso."

( Henry Ford) 


\section{RESUMO}

O presente estudo investiga o impacto de treinamento gerencial sobre a aplicação e os resultados do programa de gestão de desempenho. O referencial teórico abordou algumas definições de avaliação de desempenho e gestão de desempenho para situar a presente pesquisa em sua investigação. Os aspectos gerais sobre treinamento, desenvolvimento e educação possibilitaram identificação dos conceitos, dos modelos de avaliação de um treinamento. Ressaltou a relevância do sistema de avaliação de desempenho e as medidas de mensuração das variáveis que compõe o treinamento. No que se refere ao processo de aprendizagem do indivíduo a abordagem é relativa ao processo como um propagador do aprendizado para o seu ambiente de trabalho. E, ainda, explanação das teorias que fundamentam o planejamento instrucional de um curso. A metodologia qualitativa utilizada permitiu a partir das análises dos documentos referentes ao treinamento, a resultados da avaliação de reação dos participantes ao treinamento e dos resultados da aplicação do programa de gestão de desempenho, descrever os processos de avaliação de desempenho individual da organização e de planejamento do treinamento gerencial, analisar o desenho instrucional do curso, identificar os resultados da avaliação de reação em relação ao curso e identificar o impacto do treinamento gerencial com base nos resultados das Avaliações de Desempenho realizadas pelos ex-participantes. A conclusão é de que há necessidade de treinamento para os avaliadores do programa de gestão de desempenho. Quanto ao planejamento do esboço instrucional há alguns problemas que devem ser objeto de modificação, para buscar assegurar um melhor resultado de treinamentos futuros. No que se refere à satisfação dos treinandos com o treinamento, este, não assegurou o correto uso dos conhecimentos abordados no curso. $\mathrm{O}$ treinamento não contribuiu adequadamente para o alcance de resultados das avaliações de desempenho procedidas pelos participantes. Além disso, esta pesquisa propiciou acréscimo de conhecimentos sobre os assuntos abordados.

PALAVRAS-CHAVES: Gestão de Desempenho, Treinamento, Avaliação de Treinamento, Avaliação de Reação. 


\section{LISTA DE FIGURAS}

Figura 1 - Etapas de um modelo integrado de gestão de desempenho 16

Figura 2 - Conceitos de desenvolvimento, educação, treinamento e instrução 24

Figura 3 - Modelo de Treinamento, Desenvolvimento e Educação, com adaptações 25

Figura 4 - Modelo de Avaliação Integrado e Somativo - MAIS 27

Figura 5 - Modelo de Avaliação de Impacto de Treinamento no Trabalho - IMPACT 28 


\section{LISTA DE QUADROS}

Quadro 1 - Descrição dos planos de aula do treinamento gerencial para a aplicação do Programa de Gestão de Desempenho - GD.

Quadro 2 - Descrição dos exercícios de fixação

Quadro 3 - Detalhamento dos objetivos instrucionais do treinamento

Quadro 4 - Sugestão de desenho instrucional para o Treinamento Gerencial para aplicação do Programa de Gestão de Desempenho - GD

Quadro 5 - Informações sobre a operacionalização do GD

Quadro 6 - Resultados da análise da aplicação do GD pelos ex-participantes do primeiro grupo

Quadro 7 - Resultados análise da aplicação do programa de gestão de desempenho segundo grupo 


\section{LISTA DE TABELAS}

Tabela 1 - Distribuição das respostas de reação primeiro grupo 


\section{SUMÁRIO}

1 - INTRODUÇÃO

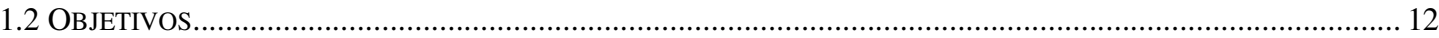

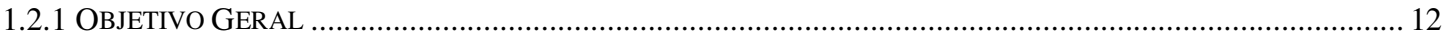

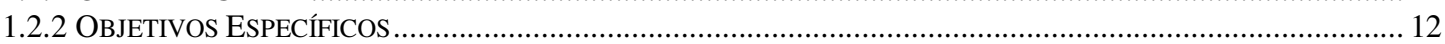

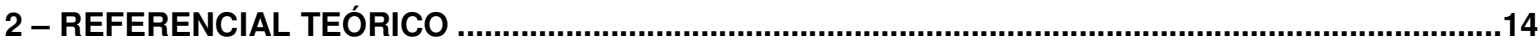

2.1 CONCEITOS ENTRE AVALIAÇÃo DE DESEMPENHO E GESTÃo DE DESEMPENHO .................................... 14

2.2 ASPECTOS GERAIS DE TREINAMENTO, DESENVOLVIMENTO E EDUCAÇÃO.............................................. 16

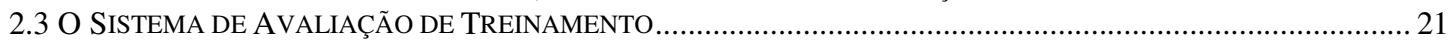

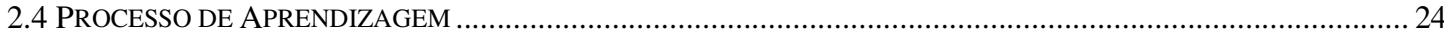

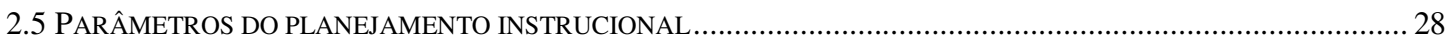



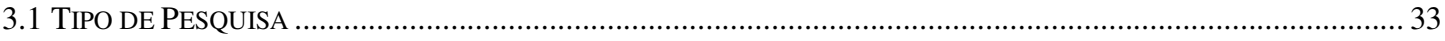

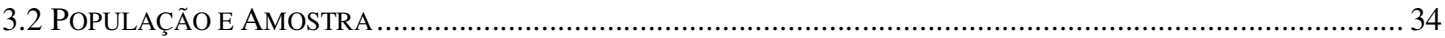

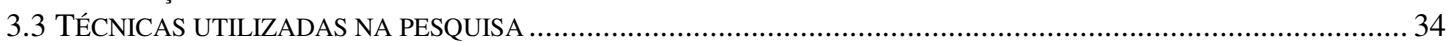



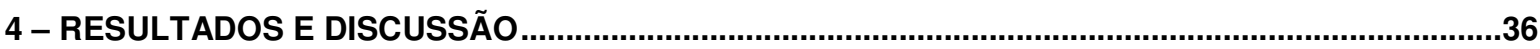

4.1 CARACTERÍSTICAS DO PROGRAMA DE GESTÃo DE DESEMPENHO ........................................................... 36

4.2 TREINAMENTO GERENCIAL PARA A APLICAÇÃO DO PROGRAMA DE GESTÃO DE DESEMPENHO .....................39

A) DESENHO INSTRUCIONAL DO TREINAMENTO

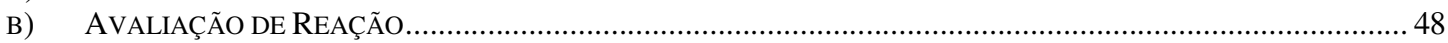

4.3 O PROGRAMA DE GESTÃO DE DESEMPENHO - GD NA PRÁTICA ............................................................. 52

4.4 COMPARAÇÃO ENTRE O DESENHO INSTRUCIONAL, A AVALIAÇÃO DE REAÇÃO E O RESULTADO DA GD NA PRÁTICA.



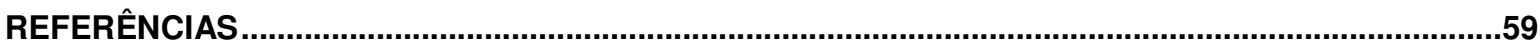

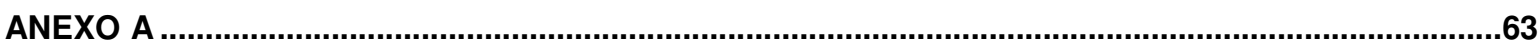

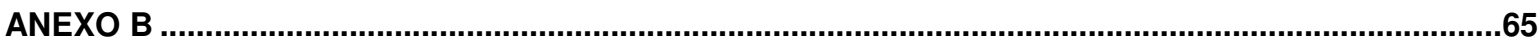




\section{1 - INTRODUÇÃO}

O contexto mundial tem mudado constantemente e as organizações para se manterem vivas precisam acompanhar as transformações diárias que ocorrem em seu ambiente externo e interno. Essas transformações impactam em diversas variáveis da organização (matéria-prima, estrutura, tecnologia) inclusive na força de trabalho demandando um empenho constante de readequação e de assimilação de novos conhecimentos. Assim, o gerenciamento e mensuração do desempenho humano, que constituem força fundamental para a concretização das mudanças no ambiente organizacional, requerem o funcionamento de um processo de avaliação de desempenho que demonstrem todas as ações empreendidas para a busca dos objetivos organizacionais (LUCENA, 2004).

A avaliação do desempenho é sempre um desafio seja na iniciativa privada seja no serviço público. Na Administração Pública a avaliação de desempenho foi instituída na década de 30 com a finalidade de concessão à promoção funcional para os servidores. Várias características do modelo de avaliação de desempenho foram criticadas e questionadas pelos teóricos. Entre essas características destaca-se a prática de avaliações de desempenho que se reportam à personalidade dos indivíduos (PINHEIRO, 1996).

Segundo Pinheiro (1996) algumas questões dificultam a imparcialidade e a eqüinanimidade da formulação de julgamento sobre o mérito, ou seja, contestam o julgamento do mérito justo da avaliação de desempenho. Estas questões são de natureza metodológica, de natureza gerencial e algumas referente às características da sociedade brasileira (cultura brasileira pautada nos padrões de conduta personalistas).

Diante de tais problemas, algumas diretrizes foram discutidas no "Plano Diretor da Reforma do Aparelho de Estado" direcionando para o estabelecimento de um processo avaliativo que fundamentasse indicadores de desempenho coerentes com o estilo de administração gerencial. Para Pinheiro (1996), a administração gerencial é caracterizada pela definição prévia e precisa dos objetivos a serem atingidos e pelo domínio a posteriori dos resultados.

Seguindo essa perspectiva, a Instituição em estudo iniciou em 1994, por meio do Plano de Ação da área de Recursos Humanos, ações que identificasse melhoria no Sistema de Avaliação de Desempenho (SAD) existente. Uma comissão composta por servidores de algumas áreas estratégicas realizou diagnóstico da atuação daquele Sistema. Essa comissão concluiu pela implantação de uma proposta que estivesse mais condizente com os objetivos da Instituição e com o desenvolvimento profissional dos servidores. 
Segundo Lucena (1977) uma avaliação de desempenho eficaz é possível quando o avaliador é preparado adequadamente para assumir esta responsabilidade, visto que a etapa mais difícil no processo de avaliação é o ato de julgar o desempenho de um indivíduo.

Essa nova abordagem contribuiu com a proposição de objetivos mais condizentes com a visão da avaliação como o processo de gestão.

Os objetivos propostos para a avaliação de desempenho da Instituição que ressaltam a importância do papel da gerencia no alcance dos seus resultados. O perfil gerencial voltado para o planejamento das metas, o comprometimento da utilização do processo de gestão de desempenho da instituição como uma ferramenta gerencial. Cabe a área de recursos humanos capacitarem esses gerentes para saberem usar com eficácia as competências e os potenciais humanos sob sua responsabilidade na busca da realização dos trabalhos e dos objetivos institucionais, desenvolvendo uma postura gerencial (LUCENA, 2004)

Visando contribuir para o alcance dos objetivos propostos e a adequada utilização da aplicação processo foi estruturado e realizado treinamento para capacitar os gerentes a aplicarem o processo de avaliação na Instituição, o Programa de Gestão de Desempenho.

O programa de gestão de desempenho - GD contempla as fases de negociação, acompanhamento e avaliação do desempenho. A negociação é o início do processo de avaliação, no qual o gerente planeja o que será realizado durante o ciclo e negocia com o colaborador as atividades e os padrões de desempenho, identifica as competências necessárias e faz recomendações para o desenvolvimento ou aperfeiçoamento profissional do colaborador. Durante o ano, o gerente faz o acompanhamento do desempenho esperado por meio de reuniões de feedbacks registrando os resultados parciais alcançados e propondo as ações a implementar referentes as dificuldades encontradas. Ao final do processo - avaliação do desempenho, os resultados alcançados já serão conhecidos, cabendo o fechamento do processo.

O treinamento objeto deste estudo é um curso de capacitação realizado especificamente para a aplicação do programa de gestão de desempenho da Instituição. $\mathrm{O}$ treinamento é uma das estratégias utilizadas pela área de recursos humanos para a construção de uma postura gerencial participativa, motivadora, com ênfase no desenvolvimento dos colaboradores e na superação de obstáculos ao desempenho eficaz e no alcance dos objetivos setoriais e institucionais.

Há outros cursos de treinamento gerencial na Instituição. No entanto, apenas um deles contempla no conteúdo programático o gerenciamento e a operacionalização dos processos de avaliação da Instituição. 
O "Curso de Formação e Desenvolvimento Gerencial", dirigido aos gerentes portadores de diploma de curso de nível médio e a outros interessados, contempla em um dos módulos o gerenciamento e operacionalização dos processos de avaliação da Instituição.

Neste curso, os resultados da aplicação do Programa de Gestão de Desempenho-GD, não apresentou resultados satisfatórios quanto a gestão do desenvolvimento e aperfeiçoamento dos colaboradores para o alcance das metas (FUB, 2006).

O outro é o "Curso de Especialização em Gestão Universitária", atualmente, denominado "Curso de Desenvolvimento Gerencial”, para os servidores e outros interessados com nível superior. Foi objeto de estudo em pesquisas recentes em nível de graduação e de especialização para avaliação do impacto do curso sobre os resultados de trabalho dos exparticipantes e posteriormente foi realizada pesquisa avaliando o impacto em profundidade. Em seu conteúdo programático, não consta módulos sobre o programa de gestão de desempenho da Instituição.

O tema desta pesquisa é a avaliação do treinamento gerencial para a aplicação do programa de gestão de desempenho e busca identificar o impacto dos resultados do treinamento gerencial na aplicação do processo de avaliação investigando os objetivos gerais e específicos seguintes.

\subsection{Objetivos}

\subsubsection{Objetivo Geral}

Identificar o impacto do treinamento gerencial sobre a aplicação e os resultados do programa de gestão de desempenho.

\subsubsection{Objetivos Específicos}

$\checkmark$ Descrever o processo de avaliação de desempenho individual utilizado na organização;

$\checkmark$ Descrever o processo de planejamento do treinamento;

$\checkmark$ Analisar o desenho instrucional do treinamento;

$\checkmark$ Descrever os resultados da avaliação de reação ao treinamento; 
$\checkmark$ Identificar o impacto do treinamento gerencial com base nos resultados das Avaliações Desempenho realizadas por ex-participantes. 


\section{2 - REFERENCIAL TEÓRICO}

Este referencial teórico está estruturado da seguinte forma: algumas definições de avaliação de desempenho e gestão de desempenho; aspectos gerais sobre Treinamento, Desenvolvimento e Educação; o processo de aprendizagem; os parâmetros para o planejamento instrucional e o sistema de avaliação de treinamento. O intuito é apresentação do processo de avaliação da Instituição e relativa ao tema em discussão citando os autores que pesquisam o assunto de modo que haja fundamentação para identificação do impacto do treinamento gerencial nos resultados da aplicação do processo de avaliação.

\subsection{Conceitos entre Avaliação de Desempenho e Gestão de Desempenho}

Segundo Marras (2000), avaliação de desempenho é uma importante ferramenta gerencial na gestão de processos que possibilita ao gestor considerar os resultados obtidos por um colaborador ou por uma equipe, em um determinado período e em termos de conhecimentos, metas, habilidades e outras áreas específicas.

A avaliação de desempenho, no conceito mais atual, é parte integrante da gestão de desempenho. Avaliar é "comparar os resultados alcançados com os esperados (planejados)", bem como verificar a atuação do indivíduo na realização da tarefa. Engloba, ainda, o ato de avaliar, o acompanhamento dos trabalhos de forma que ocorram ações corretivas para que as tarefas planejadas sejam alcançadas. (LUCENA, 1997 apud BRANDÃO; GUIMARÃES, 2001).

O conceito de avaliação de desempenho, segundo Odelius (2000, p. 71), está referenciado em um "conjunto de normas e procedimentos que possibilita o diagnóstico e gestão de desempenho, fornecendo informações para outros sistemas de administração de pessoas: desenvolvimento de pessoas, sistemas de incentivos ao desempenho satisfatório (promoções, ascensões funcionais, desenvolvimento de carreira), movimentação e alocação de pessoal, entre outros."

Segundo Guimarães (1998, apud BRANDÃO; GUIMARÂES, 2001) o "mecanismo de avaliação" definido como gestão dá o sentido subjetivo de um processo que engloba o planejamento de atividades a serem executadas, o acompanhamento do desenvolvimento delas e da avaliação dos resultados alcançados do trabalho executado pelo colaborador, atribuído a 
este em razão dos objetivos e metas organizacionais. Esse modelo, representado na Figura 1 tem fases seqüenciais e interdependentes.

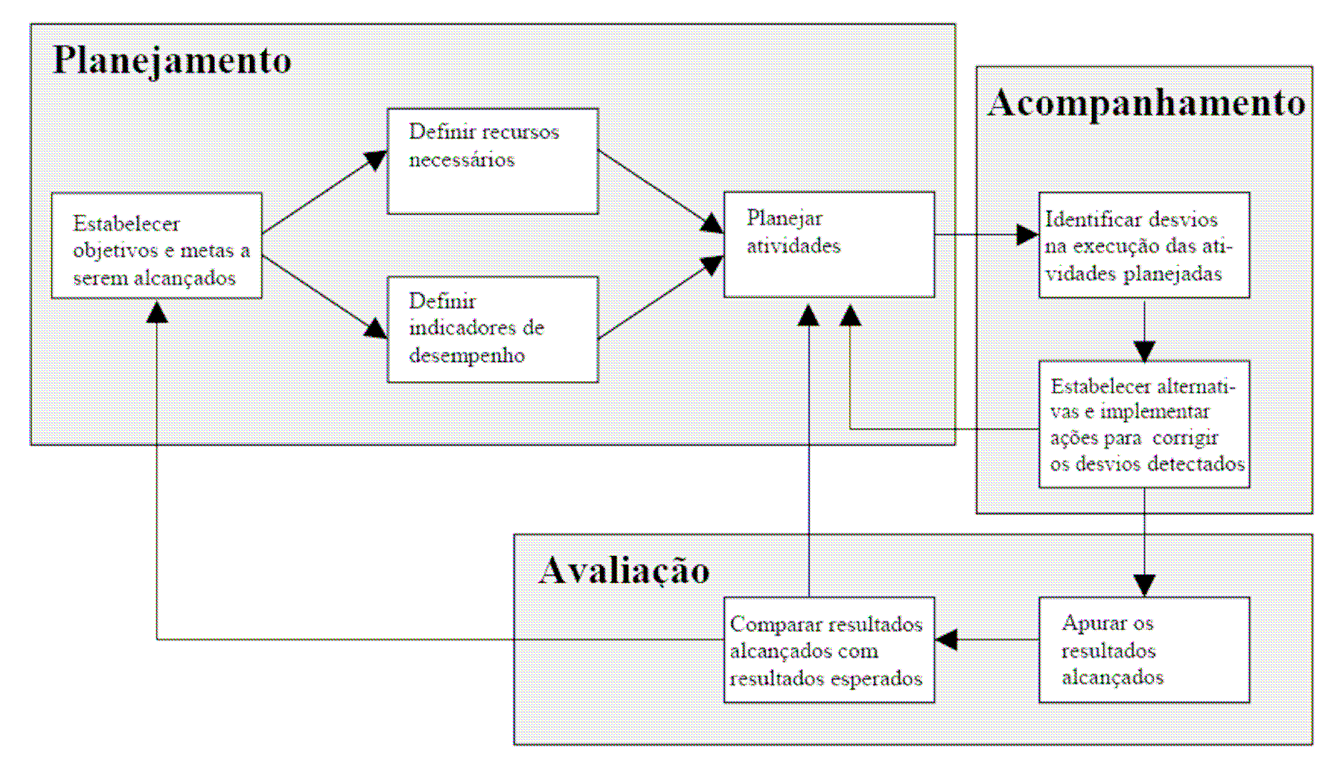

Figura 1. Etapas de um modelo integrado de gestão de desempenho Fonte: Brandão e Guimarães (2001)

O objetivo de uma avaliação de desempenho "é o acompanhamento e desenvolvimento cognitivo dos empregados durante sua permanência na organização e especificamente para medir seu nível de CHA (conhecimentos, habilidades e atitudes)" (MARRAS, 2000, p. 174)

O uso do instrumento de avaliação de desempenho é modificado e aperfeiçoado ao longo do tempo para atender as necessidades que surgem no âmbito do controle administrativo, por exemplo, para definir o grau de contribuição (individual ou grupal) nos resultados da organização, facilitar o autodesenvolvimento, fornecer feedback entre outras. (MARRAS, 2000).

Odelius (2000) aponta que a periodicidade da avaliação é variada. Umas trimestrais, outras semestrais ou anuais. No entanto a metodologia de cada sistema de avaliação de desempenho influencia a escolha da periodicidade. É recomendado para as avaliações "baseadas em objetivos" o período de um ano, vez que este tipo de avaliação está "associada a metas organizacionais definidas para o período de um ano".

Quanto à aceitação do processo de avaliação por avaliados, Odelius (2000) cita alguns autores como Bergamini (1983), Roberts (1994) e Abbad (1991), que ressaltam o treinamento 
dos avaliadores como um pré-requisito a ser atendido na busca de melhores resultados. Sugere-se que o conteúdo programático do treinamento dos avaliadores seja pautado na formação de atitudes favoráveis ao processo de avaliação, na preparação para a condução de entrevistas de avaliação bem como na informação de técnicas de observação de comportamento relevantes ao desempenho do indivíduo quanto à execução das tarefas.

A descrição do planejamento do treinamento gerencial da Instituição está no capítulo referente à discussão e resultados desta pesquisa. A seguir, faz-se uma explanação quanto as definições e peculiaridades, citada por alguns autores, dos termos treinamento, desenvolvimento e educação.

\subsection{Aspectos gerais de Treinamento, Desenvolvimento e Educação}

Os termos treinamento, desenvolvimento e educação, segundo Nadler (1984 apud TAMAYO; ABBAD, 2002) são entendidos como sinônimos por fazerem referência a práticas organizacionais direcionadas ao aumento da aprendizagem e há distinção entre os termos e estes termos.

Cada termo será discutido distintamente descrevendo as peculiaridades de cada um.

Treinamento é definido como os esforços das organizações para disponibilizar situações de aprendizagem que propiciem melhoria de desempenho no trabalho. (NADLER, 1984 apud TAMAYO; ABBAD, 2002)

O papel do treinamento para Rosemberg (2001 apud VARGAS e ABBAD, 2006) é formatar a aprendizagem em numa direção específica apoiando os indivíduos a adquirir uma nova habilidade usar um novo conhecimento de uma determinada maneira ou em um determinado nível de competência bem como em um determinado momento.

Na visão de Rosemberg (2001 apud VARGAS; ABBAD, 2006), o treinamento apresenta quatro elementos principais:

$>$ A avaliação de necessidades, derivada da intenção de melhorar o desempenho e estará refletida na preparação dos objetivos instrucionais.

$\mathrm{O}$ desenho representa as estratégias instrucionais mais adequadas à aprendizagem solicitadas e ao perfil da clientela, bem como as estratégias de avaliação que assinalam à eficácia do treinamento. 
$>$ Os meios pelo qual a instrução são entreguem, ou seja, a sala de aula, as várias tecnologias, os estudos independentes ou a combinação das diferentes abordagens instrucionais.

$>$ A avaliação, cujos níveis de complexidade variam desde situações mais simples até as mais formais com inclusão de exigência de certificação.

Segundo Vargas e Abbad (2006, p. 144) as ações específicas de indução de aprendizagem são apoiadas por formas diferentes de treinamento e pelo sistema de tecnologia instrucional. Para esses autores o treinamento se caracteriza por:

[...] eventos educacionais de curta e média duração compostos por subsistemas de avaliação de necessidades, planejamento instrucional e avaliação que visam melhoria do desempenho funcional, por meio da criação de situações que facilitem a aquisição, a retenção e a transferência da aprendizagem para o trabalho. A documentação completa de um evento educacional dessa natureza contém a programação de atividades, textos, exercícios, provas, referências e outros recursos.

O treinamento, segundo Pantoja, et al. (2005), contempla três importantes dimensões: intencionalidade na melhoria do desempenho profissional, o controle desse processo por parte da organização e a natureza processual de treinamento.

O treinamento para os cargos mais altos da organização deve abordar os valores e com um propósito maior na transmissão do conjunto de idéias que sintetizam a filosofia, a política e as diretrizes das organizações contemporâneas (PANTOJA et al., 2005)

Conforme Pantoja et al. (2005) a análise histórica e política do campo de T\&D ressaltam a dimensão conservadora do processo de treinamento nas organizações de trabalho. O treinamento como solução para problemas relativos à competência técnica, vem sendo utilizado para ajustar os indivíduos aos seus novos papéis na estrutura da empresa, tendo como funções primordiais a capacitação técnica de membros da organização e a modelagem de tipos de comportamentos compatíveis com os valores e os interesses organizacionais.

De acordo com Rodrigues, (2000, apud PANTOJA et al., 2005, p. 257) há dados recentes de pesquisas na área de avaliação de treinamento que "indicam a existência de relacionamento positivo entre comprometimento organizacional e impacto do treinamento no trabalho." E, os resultados sugerem que "indivíduos comprometidos com a filosofia e com os valores da organização tendem a apresentar níveis mais altos de transferência de novas aprendizagens no ambiente de trabalho."

Desenvolvimento, outro termo em discussão juntamente com treinamento (T\&D), era debatido dentro de subseções de psicologia do trabalho e da administração de pessoal e foi originário da expressão desenvolvimento de recursos humanos apresentado por Nadler (1984, 
apud TAMAYO; ABBAD, 2002). Para o autor desenvolvimento trata-se de um conjunto de ações que promove o crescimento individual, não estando necessariamente relacionado ao trabalho atual ou futuro e estaria embutido na expressão citada os conceitos de treinamento, desenvolvimento e educação.

Para Vargas (1996) treinamento e desenvolvimento (T\&D) é uma obtenção sistemática de conhecimentos capaz de gerar, a curto ou longo prazo, mudança na maneira de ser e de pensar do indivíduo. Esta aquisição acontece por meio da internalização de novos valores ou normas, conceitos, e da aprendizagem de novas habilidades.

Sallorenzo (2000, apud TAMAYO; ABBAD, 2002) reconhece a natureza menos específica do vínculo entre desenvolvimento e o contexto de trabalho. A autora define desenvolvimento como um processo de aprendizagem mais geral, porque propicia o amadurecimento de indivíduos de forma mais ampla, não específica para um posto de trabalho.

Vargas e Abbad (2006, p. 142) descrevem que apesar da contestação de alguns autores, Bastos, em 1991, afirmou que:

[...] desenvolvimento de recursos humanos é um conceito mais global, envolve outras funções da administração de pessoal além de treinamento; sua crescente utilização, afirma o autor, prende-se à dinâmica das próprias organizações em sua trajetória de tratar de forma mais abrangente dos profissionais que atuam na organização. Bastos ressalta que desenvolvimento engloba e não substitui o conceito de treinamento.

O termo Educação conceituado por Nadler (1984, apud TAMAYO; ABBAD, 2002) envolve estratégias de aprendizagem desenvolvidas para preparar o indivíduo para um trabalho diferente do atual em um futuro próximo, ou seja, esse conceito é aplicado ao contexto das organizações de trabalho.

Vargas e Abbad (2006) analisaram todos os conceitos e o termo educação pode ser considerado uma das formas mais amplas de aprendizagem, com um desígnio que ultrapassa o contexto específico do mundo do trabalho. As autoras demonstram as definições de educação citadas em dois importantes dicionários Houaiss e no Webster, respectivamente:

1. Ato ou processo de educar (-se). 1.1 qualquer estágio desse processo. 2. Aplicação dos métodos próprios para assegurar a formação e o desenovolvimento físico, intelectual e moral de um ser humano; conhecimento e desenvolvimento resultantes desse processo (Houaiss);

.1. Ação ou processo de educar ou ser educado. Conhecimento e desenvolvimento resultante de um processo educacional. 2. Campo de estudo que lida principalmente com métodos de ensino e aprendizagem nas escolas (VARGAS; ABBAD, 2006, p. 142). 
As autoras consideraram que o termo educação está centrado na formação e qualificação continuada profissional dos colaboradores por meio de programas ou conjuntos de eventos educacionais de média e longa duração.

Diversos estudos e pesquisas incluem uma visão integrada dos conceitos de treinamento, de desenvolvimento, de educação e que englobam mais dois conceitos: o de instrução e o de informação. (TAMAYO; ABBAD, 2002)

Vargas e Abbad (2006) escrevem que Zerbini (2003) e Carvalho (2003) incluíram no diagrama de Sallorenzo o conceito de informação e modificaram as linhas de contínua para tracejada. O conceito de informação foi considerado como uma importante na ação educacional e as alterações nas linhas do diagrama representaram os limites entre os conceitos enfraquecidos.

A Figura 2 adaptada por Sallorenzo (2000) representa a gradação de cada conceito.

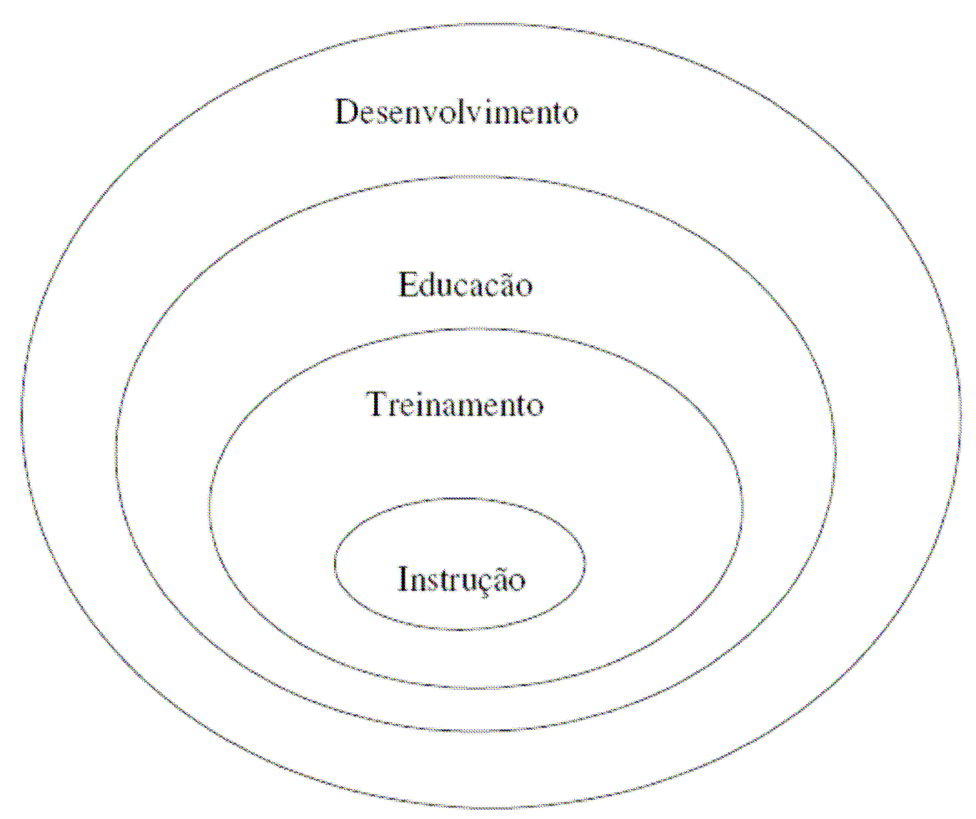

Figura 2. - Conceitos de desenvolvimento, educação, treinamento e instrução (adaptado de Sallorenzo, 2000). Fonte: Abbad e Borges-Andrade (2004, p. 271)

Para Abbad e Borges-Andrade (2004) a maior parte dos processos de TD\&E são desenhados para garantir efeitos nas equipes e na organização a partir dos indivíduos. Cada organização propicia sua condição favorável à aprendizagem contínua dos indivíduos que atuam nela, pois por intermédio dessa aprendizagem garantem-se efeitos nas equipes e na organização a partir dos indivíduos. 
O enfoque instrucional do Treinamento adotado por Borges-Andrade (1986 apud PANTOJA et al., 2005), define o modo como os profissionais de educação e treinamento conhecem, compreende e prediz as questões referentes ao ensino e à aprendizagem.

Segundo Borges-Andrade (1986 apud PANTOJA et al., 2005) o treinamento, sob o enfoque instrucional também implica mudanças de desempenho desejadas em um indivíduo bem como as ações feitas com o objetivo de alcançar mudanças.

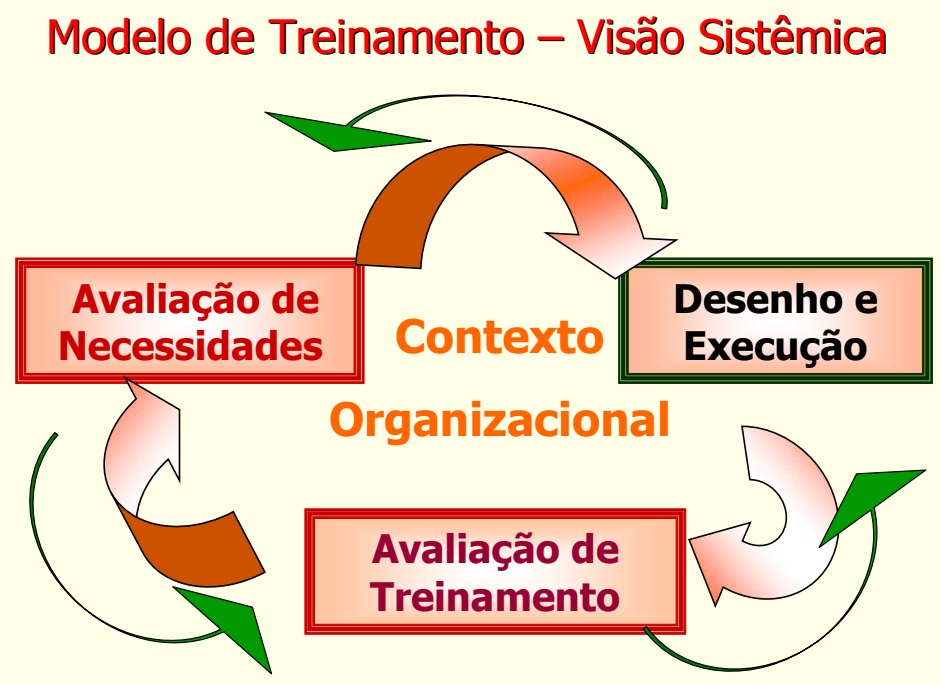

Figura 3 . Modelo de Treinamento, Desenvolvimento e Educação, com adaptações. Fonte: Borges-Andrade (2006, p. 344)

O Treinamento instrucional que é um sistema composto por elementos ou subsistemas que interagem entre si e com o ambiente externo um relacionamento de interdependência. $\mathrm{O}$ treinamento instrucional é composto por avaliação de necessidades, planejamento de treinamento e avaliação de treinamento, Figura 3.

Em seguida abordagem mais aprofundada do componente do modelo de TD\&E que se trata da avaliação de um treinamento ou curso. 


\subsection{O Sistema de Avaliação de Treinamento}

A avaliação de treinamento é uma ação sistemática de coleta de informações para viabilizar a emissão de um julgamento sobre a efetividade de um treinamento ou das ações TD\&E nas organizações. Esse componente fornece informações para os outros componentes do sistema de treinamento. A compreensão do treinamento como um todo na organização engloba alguns fatores fundamentais: as características do ambiente externo e as variáveis individuais. (PILATI, 2006)

Para Pantoja et al. (2005), o subsistema avaliação de treinamento é importante, pois identifica se ao final do curso os resultados foram positivos. Os autores salientam que Salas e Cannon-Bowers (2001) analisaram que atualmente há por parte das organizações preocupação em justificar o investimento feito em treinamento. A justificação do investimento em treinamento é pautada na melhoria organizacional, no aumento da produtividade e no desempenho das pessoas.

Um dos modelos de análise de resultados de treinamento foi desenvolvido por Kirkpatrick (1976) e ampliado mais adiante por Hamblin (1978). Esse modelo especifica os tipos de efeitos dos programas instrucionais nas organizações. Os tipos de avaliação mencionados são: reações, aprendizagem, comportamento no cargo ou impacto do treinamento, de organização e de valor final (PANTOJA et al., 2005).

Os modelos propostos por Kirkpatrick (1976) e Hamblin (1978) avaliam os resultados imediatos de um treinamento em dois níveis e, quanto aos efeitos em longo prazo, Kirkpatrick (1976) considera dois níveis e Hamblim (1978) considera três níveis. Os níveis relativos aos resultados imediatos são: reação - opiniões e satisfação dos participantes quanto a vários aspectos do curso; e, a aprendizagem - obtenção ou aperfeiçoamento de conhecimentos, habilidades e atitudes, ou seja, adquirir as competências propostas nos objetivos do evento de treinamento. Comportamento no cargo, organização ou mudanças e o valor final ou alterações são os três níveis aos efeitos em longo prazo (BORGES-ANDRADE, 2006).

Pantoja et al., (2005) relata que Hamblin (1978) considerava que os cinco níveis mantinham entre si um relacionamento positivo muito forte, porém já haviam pesquisas, como a de Alliger e Janak (1989), que mostravam que esses relacionamentos não são sempre significativos.

Pilati e Borges-Andrade (2006) descreveram os conceitos de cada um dos cinco tipos de avaliação: 
a) Reação, que levanta atitudes e opiniões dos treinandos sobre os diversos aspectos do treinamento, ou sua satisfação com o mesmo.

b) Aprendizagem, que verifica se ocorreram diferenças entre o que os treinandos sabiam antes e depois do treinamento, ou se os objetivos instrucionais do treinamento foram alcançados.

c) Comportamento no cargo, que leva em conta o desempenho dos indivíduos antes e depois do treinamento, ou se houve transferência deste treinamento para o trabalho efetivamente realizado.

d) Organização, que toma como critério de avaliação o funcionamento da organização, ou mudanças que nela possam ter ocorrido em decorrência do treinamento.

e) Valor final, que tem como foco a produção, o serviço prestado ou o alcance dos objetivos globais da organização, o que geralmente acaba implicando comparar custos do treinamento com os seus benefícios monetários ou com o lucro obtido por causa de sua realização. (PILATI; BORGES-ANDRADE, 2006, p. 363)

O Modelo de Avaliação Integrado e Somativo - MAIS proposto por Borges-Andrade em 1982, Figura 4, contempla variáveis internas aos programas de treinamento composto por cinco componentes (insumos, procedimentos, processo, resultados e ambiente que contempla a avaliação de necessidades, a disseminação, o apoio e o resultado a longo prazo) e prevê a influência de variáveis externas sobre os resultados. Segundo o autor, é a investigação conjunta dessas variáveis que permite fornecer informações precisas sobre como elas estão envolvidas no treinamento, podendo-se assim propor mudanças e melhorias no treinamento e em seus subsistemas (BORGES-ANDRADE, 2006).

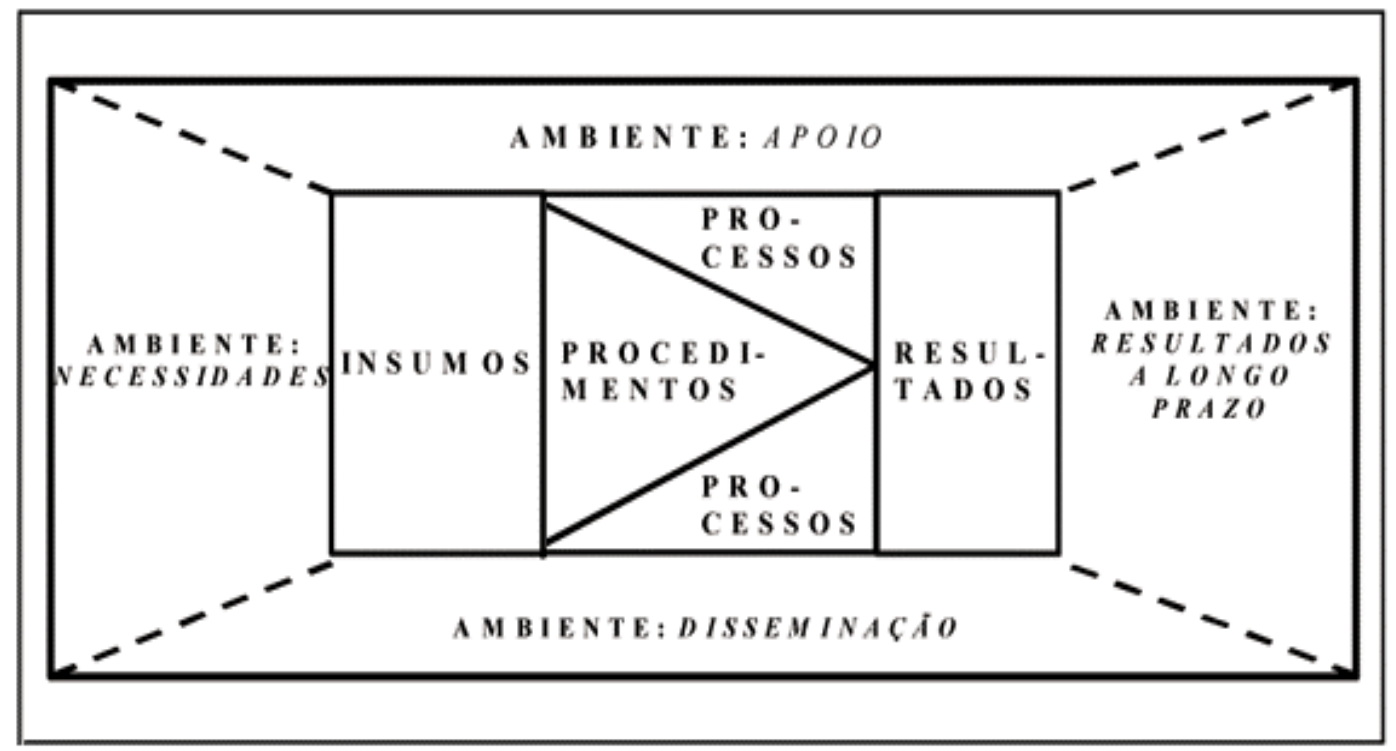

Figura 4. Modelo de Avaliação Integrado e Somativo - MAIS

Fonte: Borges-Andrade (1982, p. )

A variável insumos do MAIS são os fatores físicos e sociais e aos estados comportamentais e cognitivos, anteriores à instrução, que podem afetá-lo ou os seus 
resultados; o componente procedimentos é, principalmente, as estratégias instrucionais usadas em TD\&E para a facilitação ou produção de resultados instrucionais ou a aprendizagem; o componente processos é referente ao comportamento do aprendiz, à medida que os procedimentos são implementados; a variável resultados são produzidos pelos eventos ou programas de TD\&E; o ultimo componente do MAIS o ambiente são as condições, atividades e eventos da organização. Este componente representa o contexto de TD\&E determinando-o, modificando-o e afetando-o. Está dividido em quatro subcomponentres; avaliação de necessidades - lacunas entre desempenhos esperados e realizados; apoio ou suporte - perpassa todos os momentos do evento; disseminação - deseja que o evento de TD\&E seja um sucesso e tem o potencial de influenciar todos os demais componentes; e, resultados a longo prazo são conseqüências ambientais a serem verificadas na avaliação dos resultados esperados quanto dos inesperados (BORGES-ANDRADE, 2006).

O Modelo Integrado de Avaliação do Impacto do Treinamento no Trabalho IMPACT, desenvolvido por Oliveira-Castro (1999) com base no Modelo MAIS, exposto na Figura 5, considera o valor preditivo de múltiplas variáveis e agrega, em uma única abordagem, a avaliação dos três níveis de avaliação: reação, aprendizagem e impacto.

O modelo contempla sete variáveis (suporte organizacional, características do treinamento, características da clientela, reações, aprendizagem, suporte à transferência e impacto do treinamento no trabalho).

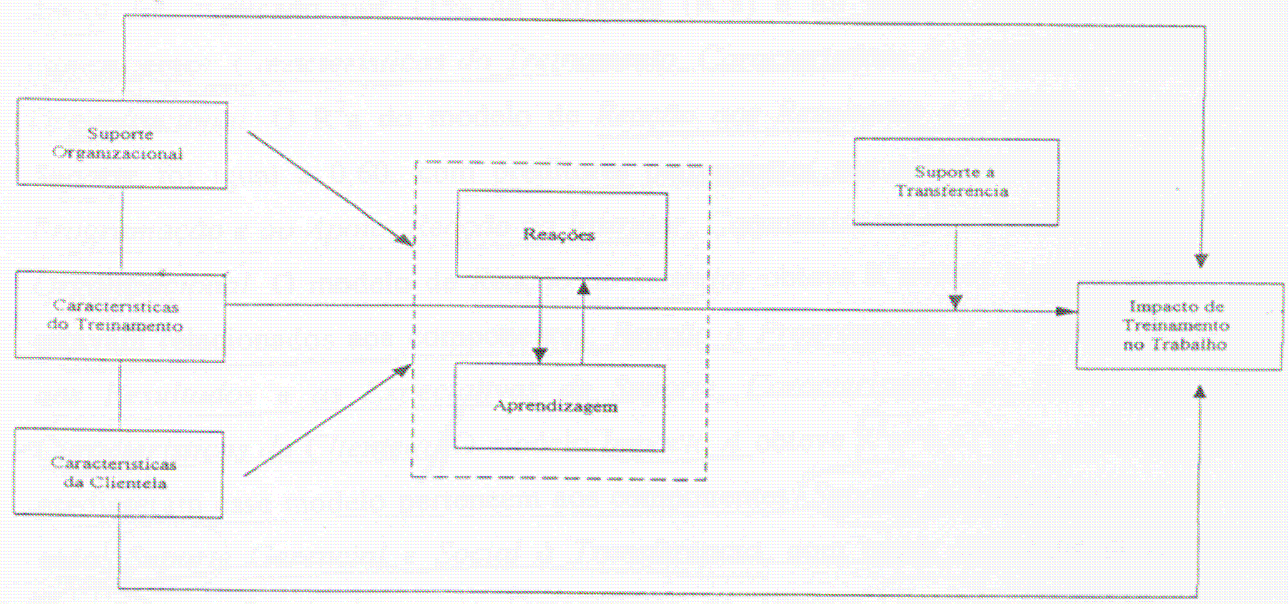

Figura 5. Modelo de Avaliação de Impacto de Treinamento no Trabalho - IMPACT.

Fonte: Oliveira-Castro (1999, p. 99) 
Dos níveis de avaliação demonstrados, o componente denominado Características do Treinamento e Reação constituem o foco do presente estudo. Para Pantoja et al. (2005) o nível comportamento no cargo foca o impacto do treinamento sobre o desempenho do treinado em seu contexto de trabalho.

O estudo da avaliação de treinamento com a utilização do modelo MAIS, segundo o autor, poderá ser convertido "em um gerador de novas questões, um formulador de outros problemas e uma ocasião para revalidar, redefinir ou rebater os princípios e o referencial teóricos utilizados no planejamento e desenvolvimento de TD\&E”. Logo, a avaliação do treinamento não tem a função de construção "do conhecimento, a partir de pesquisas aplicadas" e não apenas o papel de apreciação do mérito ou do valor de um evento. (BORGES-ANDADE, 2006, p. 357)

\subsection{Processo de Aprendizagem}

A aprendizagem é um processo psicológico que ocorre no nível do indivíduo (PANTOJA; BORGES-ANDRADE, 2002).

Segundo Zerbini (2003) somente os indivíduos são capazes de aprender, mas é possível entender como ocorre a transferência de aprendizagem do nível individual para os outros níveis da organização (grupal e organizacional).

Corroborando este conceito Abbad, Nogueira e Walter (2006) definem aprendizagem como um processo que ocorre no nível do indivíduo (micro), podendo, propagar-se para níveis mais abrangentes de análise como as equipes (meso) e organizacional (macro).

Para Biggs (1982, apud ABBAD; NOGUEIRA; WALTER, 2006) aprendizagem não são heranças genéticas, são mudanças duradouras e são conseqüências de situações peculiares vivenciadas pelo indivíduo em seu contato com o ambiente.

O conceito de aprendizagem originário da Psicologia possui uma heterogeneidade de definições. Dependendo da teoria na qual se baseia o autor da definição (cognitivista e comportamentalista) são identificados as condições necessárias à aprendizagem de CHAs exigidos no trabalho. A aprendizagem é vista como resultante da experiência de interação do indivíduo com o ambiente, ou seja, são mudanças, não resultantes exclusivamente de motivação com o contexto, que acontecem no comportamento da pessoa (ABBAD; BORGES-ANDRADE, 2004). 
Existem dois tipos de aprendizagem, a natural ou espontânea e a induzida. A aprendizagem natural ou espontânea, de um modo geral, acontece pela observação, tentativa e erro, contatos informais com outras pessoas, e quando se trata de organizações e trabalho darse com contatos formais e informais e também com materiais de apoio ao trabalho (ABBAD; NOGUEIRA; WALTER, 2006).

Conforme Abbad, Nogueira e Walter (2006) os resultados de aprendizagem alcançada pelos treinamentos são classificados por sistemas que fazem parte da teoria instrucional. Estes sistemas são: o proposto por Gagné (1974), as taxonomias de Bloom e colaboradores (1972) e as abordagens de Ausubel (1968), Anderson (1968) e Merrill (1983), apresentados em detalhes em seguida.

As taxonomias adequadas para desenhar e/ou avaliar um treinamento são as do domínio cognitivo, afetivo e psicomotor. As taxonomias mais aplicadas são as do domínio cognitivo visto que em contexto de treinamentos nas salas de aulas cuida-se mais de cognição. A classificação do domínio afetivo, ou aprendizagem afetiva tem sido considerada no esboço instrucional, na execução e avaliação, também, na instrução em sala de aula, no treinamento e na pesquisa. A classificação do domínio psicomotor se refere aos resultados de empreendimentos individuais, tem menor peso de credibilidade e falta suporte empírico (RODRIGUES Jr., 2006).

As taxonomias do domínio cognitivo são quatro, no entanto, a maior parte delas falta comprovação empírica para satisfazer as condições de cumulatividade (uma categoria de uma taxonomia abranja as categorias anteriores), de hierarquia (cada categoria é maior do que a anterior e inferior a subseqüente) e de eixo comum (base, entidade, princípio, constructo). (RODRIGUES Jr., 2006).

A primeira das hierarquias a respeito de processos cognitivos a tornar-se conhecida entre educadores e psicólogos educacionais foi a Taxonomia de Objetivos Educacionais Domínio Cognitivo (TOE:DC), proposta por Bloom e seus colaboradores (1956, 1972 e 1974), composta por 06 (seis) categorias - conhecimento, compreensão, aplicação, análise, síntese e avaliação - e, a "complexidade dos processos intelectuais" é o seu princípio organizador (RODRIGUES Jr., 2006, p. 284).

O modelo de estrutura do intelecto, de Guilford (1967), é a segunda contribuição para o delineamento da instrução e da aprendizagem. O modelo serve para descrever a realização da aprendizagem em diferentes níveis e para apontar os procedimentos que efetivaram os diferentes níveis de aprendizagem. (RODRIGUES JR., 2006). 
De acordo com Rodrigues (2006), outra contribuição importante para o planejamento da aprendizagem e da instrução foi feita por Gagné (1974) e Gagné e Briggs (1974). Eles reconhecem cinco categorias de resultados de aprendizagem - intelectual, estratégias cognitivas, informação verbal, habilidades motoras e atitudes (1974b). Focando especificamente o aspecto cognitivo, estes autores distinguem 08 (oito) tipos de aprendizagem - de sinais, de estímulo-reação, em cadeia, de associações verbais, de discriminações múltiplas, de conceitos, de princípios e de resolução de problemas. Gagné definiu esta taxonomia em sistema de hierarquia de aprendizagem a qual integra em um mesmo continuиm cognição, psicomotricidade e atitudes, ou seja, não abordam essas manifestações de aprendizagem em domínios distintos (RODRIGUES Jr., 2006)

A última contribuição referente aos processos cognitivos é o proposto por Biggs e Collis (1982) chamada Taxonomia SOLO - Structure of Observed Learning Outcome. Concentram-se no aspecto que mostra o modo como se aprendeu o que foi aprendido, está ancorado na proposta da psicologia desenvolvimentista de Piaget, e deriva em três categorias de aprendizagem: pré-esturutural, uniestrutural e multiestrutural. Este modelo não oferece evidencia empírica sobre cumulatividade, hierarquia e eixo comum (RODRIGUES Jr., 2006).

A taxonomia do domínio cognitivo, proposto por Bloom e seus colaboradores (1972 e 1974) que contempla 06 (seis) categorias de objetivos de ensino foi descrito por Abbad e Borges-Andrade (2004), bem como, por Rodrigues Jr. (2006) e na ordem crescente de complexidade, quais sejam:

- conhecimento, quando se deseja que o aluno memorize informação (datas, nomes, locais, dados, procedimentos, teorias, fórmulas, classificações, e outras);

- compreensão, quando se quer que o aluno transforme uma informação original - para expandi-la ou resumi-la;

- aplicação, representa a proposição de um processo intelectual de resolução de problemas ou situações específicas com o apoio de informações comuns;

- análise, processo intelectual, ou seja, nível mais avançado de complexidade pelo qual se enfatiza a capacidade de desdobramento de uma teoria, produto ou informação em partes indispensáveis;

- síntese, processo reverso a análise, representa resultados de aprendizagem, e implica ao aluno a produção de algo novo e pessoal partindo da informação conhecida, oriunda da instrução; e, 
- avaliação, categoria mais complexa é a capacidade intelectual de emitir com julgamento com base em critérios, ou seja, exame acerca do valor de idéias, informações, métodos, trabalhos, teorias, produtos, etc..

A Taxonomia do domínio afetivo tem apenas uma taxonomia é a Taxonomia de Objetivos Educacionais: Domínio Afetivo (TOE:DA) de Bloom et al., (1972). Seu princípio organizador é a internalização de valores e ideais. O domínio afetivo, no que se refere, aos treinamentos foi lembrado por Borges-Andrade e Lima (1983) que os "três aspectos compreendidos na sigla CHAs, designativa de competências, habilidades e atitudes", as atitudes representam aspectos afetivos objetos de treinamentos (RODRIGUES Jr., 2006, p. 283)

Segundo Rodrigues Jr. (2006), é composta de 05 (cinco) categorias organizadas do menor para o maior grau de internalização:

- aquiescência: uma postura de tolerância passiva do aluno em relação ao valor que se tem em vista na instrução;

- resposta: representa a saída do aluno do estado de passividade tolerante para o de aceitação ativa do valor;

- valorização: adesão consistente e continuada do aluno em relação ao valor que se tem em vista na instrução;

- organização: capacidade de o aprendiz posicionar-se frente a valores antagônicos ou correlatos; e, o nível mais profundo de internalização de um valor a;

- caracterização: identificação pessoal entre o aprendiz e o valor almejado.

Quanto às Taxonomias do domínio psicomotor, Rodrigues Jr. (2006) considera que são resultados de empreendimentos individuais; os sistemas de classificação de que se dispõe tem menor peso de credibilidade, além de lhes faltarem suporte empírico para os três princípios definidores de taxonomias (cumulatividade, hierarquia, eixo comum). As três Taxonomias para o domínio psicomotor são: a de Manilla que tem 05 (cinco) categorias conhecimento da metodologia, preparação, execução consciente, automatização e reorganização; a de Harrow a mais detalhada e elaborada das três e constituída de 06(seis) categorias - movimentos reflexos, movimentos básicos fundamentais, habilidades de percepção, habilidades físicas, movimentos hábeis e comunicação não-discursiva. Cada categoria é dividida em subcategorias e estas ainda são desdobradas em outras subcategorias. 
A outra taxonomia do domínio psicomotor é a de Simpson (1966) elas são baseadas no princípio da complexidade dos movimentos e constitui 05 (cinco) categorias:

- percepção: menos complexa, reúne os objetivos nos quais o aprendiz dá-se conta cognitiva, visual e auditivamente, ou de outra forma, da ação ou do conjunto de ações a serem executadas;

- posicionamento: posturas corretas realizadas pelo aprendiz que são necessáia à execução de uma dada ação;

- execução acompanhada: movimentos realizados pelo aprendiz com assistência e suporte do instrutor;

- mecanização: ação independentre do aprendiz e também pode ser passível de erros com maior ou menor freqüência; e,

- completo domínio de movimentos: é uma performance fluente, onde os erros são raros ou inexistentes

As taxonomias são de grande valia no delineamento de objetivos para um curso ou treinamento. Elas fornecem uma excelente estrutura para o apoio a instrução e possibilita elaboração de formas e instrumentos de avaliação válidos e confiáveis para a avaliação da aprendizagem (RODRIGUES Jr., 2006).

Algumas questões relativas ao planejamento instrucional à luz da teoria serão expostas em seguida.

\subsection{Parâmetros do planejamento instrucional}

As abordagens teóricas que fundamentam o planejamento instrucional são as bases para a ocorrência da aprendizagem. Dentre elas há a teoria de aprendizagem, a teoria instrucional e as abordagens de desenho instrucional. Há distinção entre cada uma delas bem como há semelhanças. Abbad, Nogueira e Walter (2006) em uma comparação entre as teorias tem-se que:

- Quanto à classificação: a teoria da aprendizagem é descritiva e não prescritiva; a teoria instrucional é prescritiva e descritiva e as abordagens de desenho instrucional são prescritivas;

-Quanto às características: a teoria de aprendizagem (descrevem processos individuais básicos, estruturas cognitivas subjacentes à aprendizagem ou relações entre eventos), a teoria instrucional (descrevem o modo pelo qual condições externas podem 
facilitar o processo interno de aprendizagem e também prescrevem eventos instrucionais gerais, aplicáveis a qualquer tipo de treinamento) e as abordagens do desenho instrucional (prescrevem métodos, estratégias, ferramentas e recursos de ensino. E ainda, detalham procedimentos instrucionais específicos);

- Quanto aos autores: a teoria de aprendizagem tem como autores: Skinner, (1969/1980) e Anderson (1983), a teoria instrucional: Gagné (1985 e 1988); Bloom e colaboradores (1972 e 1974); Ausubel (1968); e, Regeluth, (1999), e as abordagens do desenho instrucional são as descritas por Hannafin, Land e Oliver (1999); Jonanssen (1999); Mayer (1999); Schank, Berman e Macpherson (1999).

A teoria do desenho instrucional oferece um guia a respeito de como ajudar as pessoas a aprender melhor, quer esse aprendizado se trate dos domínios cognitivos, quer do emocional, quer do social, quer do físico. Algumas características básicas de uma teoria do desenho instrucional, segundo Reigeluth (1999, apud ABBAD; NOGUEIRA; WALTER, 2006) são:

\footnotetext{
- ser orientada para o desenho, ser orientada para o alcance dos objetivos, ou seja, ser prescritiva, oferecendo informações aos profissionais de treinamento sobre quais métodos utilizar, de modo a alcançar os objetivos esperados;

- identificar métodos instrucionais, ou seja, formas de apoiar e facilitar a aprendizagem e situações na qual cada método é aplicável. As situações são influenciadas pelas condições instrucionais (natureza dos resultados almejados, características do aprendiz e do ambiente de aprendizagem e restrições ambientais) e pelos resultados desejados da instrução (efetividade, eficiência e motivação do aprendiz).

- definir componentes do método, em detalhe, partindo-se do pressuposto de que os métodos podem ser decompostos em vários pedaços ou partes.

- trabalhar com a idéia de que os métodos são probabilísticos, e não determinísticos, ou seja, os métodos não garantem que os resultados desejados sejam alcançados, mas aumentam a probabilidade, visto que, em eventos instrucionais, vários são os fatores intervenientes (situações e variáveis, por exemplo) (ABBAD; NOGUEIRA; WALTER, 2006, p. 268).
}

Campos e colaboradores (1998, apud ABBAD; NOGUEIRA; WALTER, 2006) definem desenho instrucional como sendo um ciclo de atividades fundamentadas em uma teoria de aprendizagem na qual são definidos os objetivos educacionais, as informações necessárias e o modelo de avaliação.

Morrison, Ross e Kemp (2001, apud ABBAD; NOGUEIRA; WALTER, 2006) asseguram que os aprendizes, os objetivos, os métodos e a avaliação são subsídios chaves do processo de desenho instrucional e estão interligados. Com relação aos aprendizes, é preciso identificar as características dos mesmos. Os objetivos nos indicam o que os alunos precisam aprender ou demonstrar, os métodos se referem às estratégias instrucionais que possibilitam 
ao aluno aprender melhor e, finalmente, a avaliação funciona para definir em que medida a aprendizagem foi alcançada.

Reiser e Dick (1996, apud ABBAD; NOGUEIRA; WALTER, 2006) seguem a mesma teoria e recomendam quatro etapas chaves que perpassam o processo de desenho instrucional recomendadas naquela teoria:

\footnotetext{
- identificar os objetivos gerais e específicos em termos do que se espera que o aprendiz atinja;

- planejar atividades instrucionais que podem auxiliar os aprendizes que a alcançar os objetivos determinados;

- desenvolver instrumentos de avaliação que mensurem o alcance desses objetivos;

- revisar a instrução, analisando a performance do aprendiz com relação a cada objetivo e a reação dos estudantes e cada atividade instrucional (ABBAD; NOGUEIRA; WALTER, 2006, p. 269).
}

Segundo Reigeluth (1999, apud, ABBAD; NOGUEIRA; WALTER, 2006) as teorias do planejamento instrucional "fornecem diretrizes concretas sobre como facilitar a ocorrência de certos processos de aprendizagem". Para a realização da avaliação com base no modelo MAIS de Borges-Andrade (1982), de programa instrucional são necessárias responder as algumas perguntas:

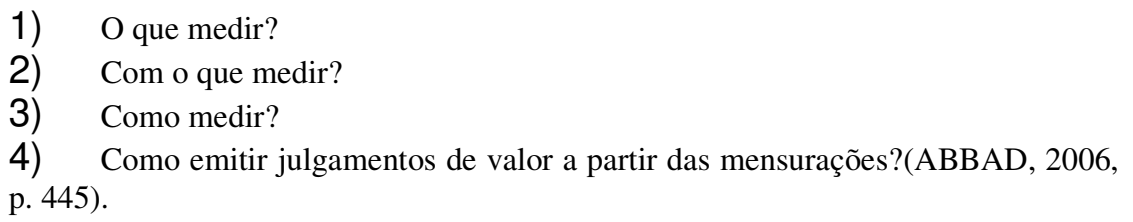

Segundo Pilati e Borges-Andrade (2006) a resposta a pergunta "O que medir?" reporta à mensuração de satisfação do treinamento no trabalho, por meio de um único item (medida global) ou de vários itens, que direcionem o foco dos aprendizes para as medidas de avaliação envolvidas na realização do evento sobre o qual se almeja a obtenção de indicadores de satisfação dos respondentes. No caso em estudo trataremos inicialmente aos referentes a apoio à execução, procedimentos e processos que são importantes medidas de avaliação do treinamento.

Apoio são fatores contextuais que fazem parte do componente suporte do modelo MAIS (BORGES-ANDRADE, 2006). Esses fatores de contextos são: os investimentos financeiros reservados ao treinamento, ações dos pares e chefias em relação ao treinando, suporte organizacional, suporte à transferência que podem comprometer toda a seqüência do evento instrucional (do levantamento de necessidades até os resultados de longo-prazo) bem como aqueles que influenciam à execução da ação instrucional. São fatores de apoio à execução da ação de TD\&E: 
[...] instalações, coordenação do evento, serviços de secretaria, hospedagem, alimentação, equipamentos e materiais de apoio á realização do evento, mobiliário, layout das salas de aula, entre outras, em eventos presenciais e relacionados a suporte técnico ao uso de recursos e tecnologias de informação e comunicação, quantidade de participantes por tutor, qualidade da interface gráfica do curso, facilidade de acesso aos materiais, adequação das ferramentas de interação entre participantes, entre outras variáveis, em caso de treinamentos à distância mediados pela internet e outros veículos. (ABBAD, 2006, p. 444)

O apoio é componente basilar no prognóstico de impacto treinamento no trabalho, de acordo com pesquisas empíricas, pois sem o apoio inviabiliza a aplicação do aprendido pelo treinando (ABBAD, 2006).

Procedimento instrucional, no modelo MAIS, é a própria ação de TD\&E, ou seja, são as características do desenho instrucional colocadas em prática. São as operações, as ocorrências e as estratégias instrucionais usadas durante o treinamento. Os procedimentos envolvem as decisões de planejamento instrucional e/ou desempenhos de instrutores, tutores e/ou professores. A finalidade é incitar o participante a alcançar os objetivos instrucionais. Inclui ocorrências deliberadas e acidentais aptas a causar efeitos sobre os resultados esperados. A avaliação dos procedimentos instrucionais possibilita a exposição detalhada do sistema instrucional, ou seja, podem-se analisar quais características são essenciais para a obtenção dos resultados em cada ação de TD\&E (ABBAD, 2006).

São características do evento:

[...] apresentação de objetivos aos participantes, seqüência de apresentação de conteúdos, tempo destinado a atividades práticas e teóricas, tipo e origem do feedback oferecido ao participante, adequação de materiais e recursos e meios utilizados no treinamento, qualidade de demonstrações, instruções verbais, aulas expositivas, entre outras.(ABBAD, 2006, p. 443)

Processos é um dos componentes do modelo MAIS de Borges-Andrade (1986) que indica os resultados parciais ou intermediários ocorridos nos comportamentos do participante durante o evento instrucional. São analisados, sobretudo, nos processos de aprendizagem e nos demais efeitos induzidos pelas estratégias instrucionais durante a implementação do evento. São exemplos de processos:

[...] os resultados obtidos pelos participantes em exercícios práticos, tempo dedicado ao estudo individual dos materiais, número de erros ou acertos em provas, testes e similares ou número de desistentes, absenteísmo, manifestações de 
satisfação-insatisfação, qualidade da interação participante-participante, instrutorparticipante, participante-coordenação do evento, entre outras, perda ou desperdício de materiais, etc. (ABBAD, 2006, p. 443)

Algumas medidas de processos são: a) número de faltas; b) quantidade de consultas ao tutor; c) número de erros em exercícios; d) tempo de estudo individual por unidade do treinamento; e) notas em testes intermediários; f) qualidade da interação entre participante, entre outros (ABBAD, 2006).

"Com o que medir?" leva à seleção, construção e validação de instrumentos que suscitem informações válidas e precisas sobre aquilo que se quer avaliar. São geralmente usados os instrumentos de questionários, roteiros de entrevistas, de análise documental e/ou de observação. Neste estudo a análise documental do desenho instrucional do treinamento é uma dos instrumentos de avaliação.

As seqüências de atividades para a elaboração de um desenho ou plano instrucional são (ABBAD et al., 2006):

- Primeira etapa: redigir objetivos instrucionais, transformando as necessidades em objetivos, especificando os componentes dos objetivos, avaliando a qualidade dos objetivos, e,especificando os níveis de análise

- Segunda etapa: escolher modalidade na qual contempla a analise do perfil dos aprendizes e a avaliação e escolhas alternativas;

- Terceira etapa: estabelecer a seqüência, classificando os objetivos e definindo a seqüência dos conteúdos;

- Quarta etapa; selecionar ou criar procedimentos instrucionais selecionando e criando situações de aprendizagem, escolhendo os meios instrucionais e recursos e preparando os materiais de ensino;

- Quinta etapa: Definir critérios de avaliação de aprendizagem por meio de transformação de objetivos em critérios de avaliação e criação de medidas de avaliação;

- Sexta etapa: testar o desenho instrucional delineando a validação, avaliando o plano instrucional e ajustando o plano. 


\section{3 - METODOLOGIA}

Nesta etapa descreve-se a metodologia e as técnicas de pesquisa adotadas na análise documental e na avaliação do treinamento gerencial.

Vergara (2004) aponta que na literatura a definição metodológica para uma pesquisa empírica é de fundamental importância para os objetivos do pesquisador. Na metodologia se deve informar o que pretende investigar e o porquê de tal pesquisa. A seguir o tipo de pesquisa usada, a amostra pesquisada, as técnicas, os procedimentos adotados e a forma de análise dos dados coletados.

\subsection{Tipo de Pesquisa}

A metodologia aplicada nesta pesquisa está baseada na taxonomia apresentada por Vergara (2004). A autora qualifica a classificação da pesquisa em dois tipos: quanto aos fins e quanto aos meios.

Classifica-se, quanto aos fins, como uma pesquisa exploratória e descritiva. Exploratória porque ainda não se verificou a existência de estudos que abordem o impacto do treinamento gerencial sobre a aplicação do programa de gestão de desempenho, embora nos dois últimos anos tem-se intensificado estudos voltados para o impacto de outros treinamentos no âmbito funcional da Instituição. Descritiva, pois expõe as características da metodologia do treinamento gerencial utilizada para a realização do evento (Vergara, 2004).

No que se refere aos meios à pesquisa foi bibliográfica, porque recorre aos materiais acessíveis ao público em geral, investigação do referencial teórico já publicado sobre o assunto em estudo. A pesquisa bibliográfica, segundo Lakatos e Marconi (1991, p. ), "não é mera repetição do que já foi dito ou escrito sobre o assunto, mas propicia o exame de um tema sob novo enfoque ou abordagem, chegando a conclusões inovadoras."

Está pesquisa foi, também, documental, visto que analisou documentos relativos ao desenho instrucional do treinamento objeto do estudo e os resultados apresentados pelos exparticipantes na aplicação do processo de avaliação juntos aos seus colaboradores. 


\subsection{População e Amostra}

A população total, assim como universo são conceituados por Vergara (2004) como um conjunto, por exemplo, de empresas, de produtos, de pessoas, que tem as peculiaridades objeto de um estudo; e, a população amostral é uma parte da população total selecionada de acordo com algum critério de representatividade para a realização do estudo ou pesquisa.

A população foi composta pelos participantes do evento de treinamento gerencial no total de 92 gerentes. O treinamento gerencial ocorreu nos dias 8, 9 e 10 de maio de 2006 para um primeiro grupo e nos dias 24, 25 e 26 do mês de maio do ano de 2006, para um segundo grupo.

Foram convocados formalmente, 38 participantes para o primeiro grupo e 40 para o segundo grupo. Nos dias de realização do evento compareceram mais 08 pessoas no primeiro período e mais 06 pessoas no segundo.

Os gerentes que estiveram presentes no treinamento totalizam 47 e representam $51,08 \%$ do total. Foram pesquisados todos os gerentes que participaram do treinamento durante dois dias ou mais, ou seja, 39 gerentes, o que equivale a 82,97\% dos gerentes que concluíram o curso.

\subsection{Técnicas utilizadas na pesquisa}

Nesta pesquisa foram utilizados para a coleta de dados os documentos existentes na Instituição referente ao treinamento gerencial do Programa de Gestão de Desempenho e referente à aplicação do programa realizada, no período de março de 2006 a fevereiro de 2007, pelos ex-participantes do treinamento, bem como os questionários com as respostas da avaliação de reação feita pelos ex-participantes ao final do treinamento

O desenho instrucional do treinamento descrito e exposto nos Quadro 1 e 2 foi avaliado conforme lista de verificação para análise de estratégias instrucionais proposta por Reigeluth (1999 apud, ABBAD et al., 2006), e adicionalmente com base em aspectos relevantes ao processo de planejamento instrucional, descrito por Abbad et al. (2006).

O questionário “Avaliação do Módulo pelo Servidor” (ver Anexo A) desenvolvido por Borges-Andrade (1982, apud OLIVEIRA-CASTRO, 1999) foi adaptado e contempla os seguintes tópicos: programação, apoio ao desenvolvimento do treinamento, aplicabilidade e utilidade do treinamento, resultado do treinamento, suporte organizacional: e, quanto à 
avaliação do tutor têm-se os tópicos: desempenho didático, domínio de conteúdo e entrosamento com os treinandos; por último há campo para comentários/críticas/sugestões. A escala utilizada para avaliação é: ruim, insuficiente, regular, bom e ótimo.

\subsection{Procedimentos de coleta e análise dos dados}

A análise documental está baseada no "Roteiro de análise dos materiais didáticos" ver Anexo B (OLIVEIRA-CASTRO, 1999) para avaliação do segundo componente do IMPACT, Características do Treinamento, preditor de impacto do treinamento no trabalho. Os documentos, assim como as análises de materiais didáticos, foram analisados com base em variáveis do modelo elaborado por Borges-Andrade (1982). 


\section{4 - RESULTADOS E DISCUSSÃO}

\subsection{Características do Programa de Gestão de Desempenho}

O Programa de Gestão de Desempenho, de acordo com norma da organização, está instituído com o intuito de criar um ambiente de gerenciamento contínuo e sistematizado do desempenho do pessoal técnico-administrativo, denominado GD. Está normalizado na Instituição desde 1998, pela Instrução da Reitoria n. 006/1998. Atualmente, vigora a Instrução da Reitoria n. 003/2001, após realização de ajustes e de simplificação da metodologia.

Os objetivos do GD são: definição e mensuração do grau de contribuição de cada colaborador na consecução dos objetivos da Unidade à qual está lotado; possibilidade de o colaborador identificar e buscar os meios necessários ao autodesenvolvimento, por meio de sua participação no processo avaliação e do conhecimento dos resultados da respectiva avaliação; aumento da produtividade e da qualidade dos serviços prestados e prontidão no atendimento da área-fim, bem como obtenção de subsídios a decisões na área de Recursos Humanos, relativas à situação funcional do colaborador.

O GD constitui, conforme norma, instrumento de gestão de pessoas na sua relação com o trabalho e com os objetivos das Unidades e da Instituição em parceria com outros processos gerenciais (treinamento e desenvolvimento, movimentação, remoção, etc.).

Objetivando a sensibilização da mudança pelo comprometimento o programa de gestão de desempenho está dimensionado nas seguintes etapas e ações:

- comunicações sobre o processo de gestão de desempenho (os objetivos, o significado, os resultados esperados, as fases da metodologia) para as Unidades da Instituição;

- treinamento dos avaliadores: programa formal, que abrange toda a grandeza do programa (resultados esperados, responsabilidades dos avaliadores, atitudes e comportamentos dos mesmos, operacionalização das fases); e,

- relatório final com os dados quantitativos e qualitativos dos resultados alcançados pela Aplicação e pela Capacitação dos gerentes referentes a toda a dimensão do Programa.

As comunicações sobre o GD são enviadas as Unidades da Instituição, por meio de documento formal, no início, durante e ao final do ciclo de avaliação. O treinamento dos avaliadores, objeto de estudo desta pesquisa, está descrito no próximo item deste capitulo. $\mathrm{O}$ relatório final com as informações obtidas sobre o funcionamento, os resultados e as ações implementadas do GD são apresentadas a direção geral da área de recursos humanos com 
análises, comentários, conclusões e recomendações para aperfeiçoamento do processo no ciclo seguinte.

O GD ocorre em ciclos anuais. A clientela é composta, em média, por 2.551 colaboradores, servidores do quadro de pessoal permanente e prestadores de serviços. Os avaliadores são os gerentes, aquele que está no cargo de direção, função gratificada, ou responsável pela supervisão das tarefas realizadas pelos colaboradores. Na maioria das vezes, exercem suas funções gerenciais, no mesmo espaço físico dos seus colaboradores. Quando ocupam espaços físicos diferentes dos colaboradores, as atividades no dia-a-dia são verificadas, por meio dos procedimentos e das rotinas ou de outros meios que estão acessíveis ao acompanhamento da avaliação do gerente. Os docentes com funções gerenciais são participantes do processo de avaliação como avaliadores, ou seja, não estão sujeitos ao GD como avaliados.

O Manual do GD descreve detalhadamente a metodologia do Programa que contempla três fases: negociação, acompanhamento do desempenho e avaliação do desempenho.

Na negociação, conforme a norma e o Manual, o gerente planeja as atividades anuais a serem alcançadas pelo Setor. Em seguida, se reúne com cada colaborador e, em conjunto, negociam as atividades e seus respectivos padrões de desempenho, analisam as competências e direcionam as recomendações que serão necessárias para o alcance de resultados das Unidades. Durante o acompanhamento do desempenho, gerente e colaborador, se reúnem duas vezes ou mais, para verificarem o andamento da execução das atividades identificando os resultados parciais e propondo ações a implementar que contribuam para o alcance das atividades. Por fim, voltam a se reunir ao final do ciclo para avaliação do desempenho e registro final do desempenho alcançado.

Os registros são efetuados no instrumento denominado "Gestão de Desempenho Individual". Os gerentes também são avaliados por seus superiores e os registros das ocorrências são efetuados no instrumento denominado "Gestão de Desempenho - Gerencial".

Os instrumentos são compostos por campos numerados seqüencialmente. Os campos referentes à Negociação contêm os itens para descrição das atividades e seus padrões de desempenho (prazo, qualidade e quantidade). Consta também, na negociação, campo chamado Análise da Capacitação e Recomendações para identificar e assinalar as competências. As recomendações são realizadas quando forem necessárias; Os campos referentes ao Acompanhamento são para o registro das datas das reuniões, narração sucinta dos resultados parciais identificados em cada reunião referente, inclusive, ao suporte ambiental dado pela organização para a execução das atividades inerentes aos cargos 
ocupados pelos avaliados, bem como identificar as dificuldades do colaborador que afetam o seu padrão de desempenho no trabalho e das ações que serão necessárias implementar para que a meta seja alcançada de forma positiva.Por fim os campos da Síntese dos Resultados são registrados na última etapa - Avaliação do desempenho - para que os gerentes, com a participação dos avaliados, resgatem as metas negociadas e os registros dos acompanhamentos feitos para então identificar e registrar as metas que foram alcançadas totalmente (AT) e as que não foram atingidas (NA) registrando no Relatório Final do Desempenho a classificação alcançada pelo avaliado. No instrumento avaliativo, em questão, não há escores para a avaliação. O critério de avaliação final do desempenho dos colaboradores é definido por classificações de acordo com o percentual de metas atingidas, ou seja, até $20 \%$ de metas atingidas - insuficiente; de 21 a $40 \%$ :de metas atingidas - fraco; de 41 a $60 \%$ de metas atingidas - Regular; de 61 a $80 \%$ de metas atingidas - Bom; de 81 a $90 \%$ de metas atingidas - Muito Bom; e, de 91 a 100\% de metas atingidas - Excelente. (Universidade de Brasília, 2001)

Os instrumentos de avaliação são enviados a RH ao final do ciclo avaliação. A área responsável pela coordenação do Programa, com base nos formulários, registra as classificações dos avaliados, anota quem são os avaliadores de cada Unidade, identifica e faz apontamentos das ocorrências percebidas quanto aos procedimentos realizados pelos gerentes em cada fase do processo de avaliação - negociação, acompanhamento do desempenho e avaliação do desempenho. As ocorrências são referentes às facilidades e dificuldades quanto à aplicação da metodologia e os procedimentos operacionais do processo. A compilação dessas ocorrências foi denominada análise qualitativa.

Ao final de cada ciclo de avaliação é elaborado relatório, que engloba os resultados da aplicação do GD feita pelos gerentes, bem como do treinamento realizado para capacitação gerencial do programa de gestão de desempenho. O Relatório gerencial demonstra os dados quantitativos e percentagem da clientela, das classificações, das Unidades envolvidas no programa e síntese dos resultados da aplicação da metodologia (correta/incorreta) pelos gerentes. Apresenta ainda, os dados dos gerentes que participaram do treinamento. De acordo, com esse relatório a análise qualitativa indica que alguns dos conhecimentos transmitidos durante o treinamento não são aplicados na realização da avaliação, sendo importante uma investigação para identificar os impactos do treinamento no trabalho e os aspectos que estão influenciando esses resultados. 


\subsection{Treinamento gerencial para a aplicação do programa de gestão de desempenho}

A preparação dos avaliadores acontece desde 1998, quando da implementação do Programa de Gestão de Desempenho, todos os anos, antes e/ou no início do período de avaliação. O curso destina-se aos gerentes da Instituição. São selecionados e convocados aqueles ocupantes de função gratificada e/ou comissionada que não participaram dos treinamentos anteriores e têm colaboradores sob sua supervisão. A convocação é enviada à Unidade do participante duas semanas antes do curso. No documento de convocação constam os dias e os horários de realização do treinamento.

O treinamento gerencial é denominado na Instituição de "Capacitação Gerencial" oferecido aos gerentes que participam do processo de avaliação da Instituição: o programa de gestão de desempenho-GD. Esta etapa busca preparar os gerentes para a realização da avaliação de desempenho de modo mais adequada.

Participam do treinamento os gerentes que assumiram uma função gerencial e que ainda não participaram do treinamento, podendo os mesmos atuarem em áreas acadêmicas ou administrativas, inclusive do Hospital Universitário da Instituição.

Os objetivos do Treinamento são: desenvolvimento de habilidades gerenciais necessárias à Gestão de Desempenho; domínio, por parte dos gerentes, de todas as fases do processo, e sensibilização dos gerentes para aceitação e envolvimento com o método avaliativo (FUB, 1997).

O Treinamento gerencial é avaliado quanto à reação dos participantes. Em 2007 não foi realizado o treinamento, visto à implementação do novo Programa de Avaliação de Desempenho baseado nas diretrizes do Plano de Carreira dos servidores técnicoadministrativos. Desse modo, este estudo buscará os dados e informações referentes ao último treinamento realizado, ou seja, em 2006.

\section{a) Desenho instrucional do treinamento}

O curso em estudo é oferecido gratuitamente, no âmbito da Instituição, mediado por instrutora técnica e material de apoio (impresso e outros). Trata-se de uma capacitação para os aplicadores utilizarem de forma adequada à metodologia do programa de gestão de desempenho no âmbito de suas Unidades. O treinamento é composto por (03) três aulas. Cada aula tem 04 horas de duração com 15 minutos de intervalo após 02 horas. 
O material instrucional do treinamento em estudo é composto por (bibliografia, norma institucional e os respectivos instrumentos avaliativos, planos de cada aula, transparências dos assuntos abordados, textos referentes a cada objetivo específico, folhas de exercício individual e em grupo). Encontra-se descritos nesse material o objetivo geral e os específicos, os conteúdos abordados, as técnicas didáticas utilizadas, a carga horária diária, lista dos procedimentos e dos recursos utilizados em cada aula, bem como orientações para execução de cada atividade de ensino. O Quadro1 apresenta essas informações para cada aula.

As aulas são seqüenciadas, por meio de exposição oral. Inicialmente os participantes respondem a um questionário que visa avaliar as percepções quanto ao treinamento com aferição das respostas em escala Likert e abordam questões sobre satisfação com o trabalho, percepção dos valores individuais e organizacionais e também sobre motivação para a aprendizagem do conteúdo do curso.

A seguir, esta pesquisa descreve com mais detalhes o conteúdo programático contido no material instrucional de cada aula para melhor compreensão da realização do curso.

A primeira aula expõe: a importância do ato de avaliar; como se inicia e termina o processo de avaliação (planejamento e comparação do desempenho apresentado e o desempenho esperado); os benefícios da avaliação para a organização, para o avaliado e para o avaliador; os erros ou efeitos que ocorrem na avaliação do desempenho; a comunicação (feedback positivo e negativo) como fator chave no processo; apresenta os principais pontos dos procedimentos do estágio probatório; reforça como acontece, de forma global, a dinâmica do processo avaliativo; apresenta a filosofia, o histórico, os benefícios de utilização, os conceitos principais e a dinâmica global do programa de gestão de desempenho-GD.

A segunda aula apresenta o conceito de negociação para o GD, quais são e como adquirir os conhecimentos e habilidades para o GD (saber quais são os objetivos instituicionais/setoriais e como efetuar o planejamento); no desenvolvimento da negociação, mostra quais os critérios para redação de metas, como definir os padrões de desempenho e como efetuar a análise da capacitação profissional por meio de competências discriminadas no Manual do GD; explica que o processo deva ser orientado para a melhoria comportamental do avaliado e como e onde formalizar esse momento.

A terceira e última aula é dividida em dois momentos (acompanhamento e avaliação do desempenho). Relata sobre os conceitos de acompanhamento e de avaliação, sobre o conhecimento e habilidades importantes nestas fases (acompanhamento do trabalho e do desempenho esperado, condições para dar e receber feedback, planejar entrevista de acompanhamento, realizar a avaliação final confrontando os resultados obtidos com as metas 
estabelecidas, bem como explica como executar a formalização), apresenta também, informações sobre as premiações ao bom desempenho e a progressão por mérito, informa sobre as discordâncias na avaliação e divulga outras ações da área técnica (consultoria interna).

A execução das atividades e exercícios de fixação propostos, de acordo com o plano de aula (ver Quadro 1) é realizada ao final de cada aula, de caráter obrigatório, com questões realizadas e discutidas em grupo. As folhas de exercícios contêm o objetivo do exercício, as instruções para a realização das atividades, o tempo e as regras para discussão e exposição das conclusões encontradas. São cinco atividades de fixação. Uma para a primeira aula, duas para a segunda aula e mais duas para a última aula. As questões abordadas são referentes ao conteúdo aprendido na aula. As atividades e exercício de fixação simulam a prática dos assuntos referenciados nos objetivos específicos de cada aula. O Quadro 2 mostra o teor das folhas de exercícios.

No material instrucional tem textos de leitura. Estes textos abordam as fases de negociação, de acompanhamento e de avaliação de desempenho relacionados à ampliação ou aquisição de habilidades e atitudes necessárias para a concretização de cada fase. 
Quadro 1 : Descrição dos planos de aula do treinamento gerencial para aplicação do Programa de Gestão de Desempenho - GD

\begin{tabular}{|c|c|c|c|c|c|c|}
\hline \multicolumn{7}{|c|}{ TREINAMENTO GERENCIAL PARA APLICAÇÃO DO PROGRAMA DE GESTÃO DE DESEMPENHO } \\
\hline Objetivo do curso & Aulas & Temas & Objetivos específicos & Conteúdo & Procedimentos & Recursos \\
\hline \multirow{3}{*}{$\begin{array}{l}\text { Desenvolver } \\
\text { habilidades } \\
\text { necessárias à Gestão } \\
\text { de Desempenho; } \\
\text { Alcance do domínio } \\
\text { por parte dos } \\
\text { gerentes de todas as } \\
\text { fases do processo e } \\
\text { sensibilização dos } \\
\text { gerentes quanto á } \\
\text { aceitação e o } \\
\text { envolvimento com o } \\
\text { método avaliativo. }\end{array}$} & $\begin{array}{l}\text { Aula } 1 \\
-4 \text { hs }\end{array}$ & $\begin{array}{l}\text { - A importância e o } \\
\text { significado da } \\
\text { Avaliação de } \\
\text { Desempenho. Os } \\
\text { métodos de } \\
\text { avaliação da } \\
\text { Instituição }\end{array}$ & $\begin{array}{l}\text { - Transmitir } \\
\text { conhecimentos sobre } \\
\text { avaliação de } \\
\text { Desempenho; } \\
\text { - Preparar para a correta } \\
\text { operacionalização dos } \\
\text { processos avaliativos da } \\
\text { Instituição. }\end{array}$ & $\begin{array}{l}\text { - Importância do processo de } \\
\text { avaliação; } \\
\text { - Os métodos de avaliação da } \\
\text { Instituição: estágio probatório e } \\
\text { GD (histórico, conceituação, } \\
\text { benefícios e fases. }\end{array}$ & $\begin{array}{l}\text { - Avaliação de } \\
\text { expectativas; } \\
\text { • Exposição oral } \\
\text { dialogada; } \\
\text { • Folhas de exercício } \\
\text { individual e para } \\
\text { discussão em grupo. }\end{array}$ & $\begin{array}{l}\text { • Canhão de projeção; } \\
\text { • documentos normativos } \\
\text { do GD (IR 003/2001 e } \\
\text { Manual); } \\
\text { - Texto: "como fazer uma } \\
\text { boa avaliação de } \\
\text { desempenho". } \\
\text { - Bibliografia. }\end{array}$ \\
\hline & $\begin{array}{l}\text { Aula } 2 \\
-4 \text { hs }\end{array}$ & $\begin{array}{l}\text { • Negociação do } \\
\text { desempenho }\end{array}$ & $\begin{array}{l}\text { - Preparar para a correta } \\
\text { operacionalização da } \\
\text { fase de negociação do } \\
\text { GD. }\end{array}$ & $\begin{array}{l}\text { - Negociação } \\
\text { conhecimentos e habilidades; } \\
\text { desenvolvimento; análise da } \\
\text { capacitação profissional; e } \\
\text { formalização da negociação do } \\
\text { desempenho - formulário } \\
\text { preenchido). }\end{array}$ & $\begin{array}{l}\text { - Exposição oral } \\
\text { dialogada; } \\
\text { - Folhas de exercício } \\
\text { individual e em grupo }\end{array}$ & $\begin{array}{l}\bullet \text { Canhão de projeção; } \\
\text { •Texto: "Maximizando o } \\
\text { Desempenho". }\end{array}$ \\
\hline & $\begin{array}{l}\text { Aula } 3 \\
-4 \text { hs. }\end{array}$ & $\begin{array}{l}\text { - Acompanhamento } \\
\text { e Avaliação do } \\
\text { desempenho }\end{array}$ & $\begin{array}{l}\text { - Preparar para a correta } \\
\text { operacionalização das } \\
\text { fases de } \\
\text { Acompanhamento e de } \\
\text { Avaliação do GD. }\end{array}$ & $\begin{array}{l}\text { - Acompanhamento } \\
\text { (conceituação, conhecimento e } \\
\text { habilidades, e desenvolvimento); } \\
\text { - Avaliação (definição, } \\
\text { desenvolvimento, formalização); } \\
\text { - Premiações e progressão por } \\
\text { mérito; } \\
\text { - Consultoria interna }\end{array}$ & $\begin{array}{l}\text { •Exposição oral } \\
\text { dialogada; } \\
\text { •Exercício em grupo }\end{array}$ & $\begin{array}{l}\text { •Canhão de projeção; } \\
\text { •Texto: "Como planejar e } \\
\text { conduzir uma reunião de } \\
\text { acompanhamento"; }\end{array}$ \\
\hline
\end{tabular}

Fonte: Material instrucional do treinamento gerencial. (Universidade de Brasília, 2006) 


\begin{tabular}{|c|c|c|c|c|}
\hline Aulas & $\begin{array}{l}\text { Tipo de } \\
\text { exercício }\end{array}$ & Objetivo do exercício & Procedimentos/Critérios & Questões para realização do exercício \\
\hline 1 & $\begin{array}{l}\bullet \text { Discussão } \\
\text { em grupo }\end{array}$ & $\begin{array}{l}\text { - Possibilitar reflexão sobre o processo de } \\
\text { avaliação de desempenho }\end{array}$ & $\begin{array}{l}\text { - Formar grupos; } \\
\text { - Distribuição de } 3 \text { perguntas para discussão entre os } \\
\text { integrantes do grupo; } \\
\text { - Os grupos terão } 20 \text { minutos para discutirem, e o } \\
\text { relator escolhido pelos membros, } 10 \text { minutos para } \\
\text { expor as conclusões. }\end{array}$ & $\begin{array}{l}\text {-1) O que é avaliação e o que não é? } \\
\text {-2) O que deve ser avaliado e o que não deve ser? } \\
\text { •3) O que se experencia como mais gratificante, ser avaliado } \\
\text { ou avaliador? }\end{array}$ \\
\hline \multirow[t]{2}{*}{2} & - Individual & $\begin{array}{l}\text { - Planejamento para o estabelecimento } \\
\text { das metas }\end{array}$ & • Não está definido & $\begin{array}{l}\text { - Definir: } \\
\text { - A) necessidades dos usuários em relação aos serviços do } \\
\text { setor; } \\
\text { - B) em que medida a estratégia atual satisfaz essas } \\
\text { necessidades; } \\
\text { - C) serviços a manter, já que apresentam os resultados } \\
\text { desejados; } \\
\text { - D) serviços a melhorar em termos de: qualidade, aumento } \\
\text { da produtividade, reformas administrativas e } \\
\text { desenvolvimento dos recursos humanos }\end{array}$ \\
\hline & $\bullet$ Em grupo & $\begin{array}{l}\text { - Capacitar os gerentes para o } \\
\text { desempenho eficaz no estabelecimento } \\
\text { de metas, bem como no preenchimento } \\
\text { do formulário }\end{array}$ & $\begin{array}{l}\text { - Formar grupos (máximo de } 5 \text { gerentes) } \\
\text { - O grupo terá } 40 \text { minutos para realizar o exercício e } \\
\text { um membro relatará o trabalho em } 10 \text { minutos. }\end{array}$ & $\begin{array}{l}\text { - Cada membro do grupo deverá estabelecer as metas de } 1 \\
\text { colaborador (Avaliação individual) ou de } 1 \text { gerente } \\
\text { (Avaliação gerencia), preenchendo o campo da Análise da } \\
\text { capacitação Profissional utilizando para isto o formulário do } \\
\text { GD }\end{array}$ \\
\hline \multirow[t]{2}{*}{3} & $\bullet$ Em grupo & $\begin{array}{l}\text { - Capacitar os gerentes para o } \\
\text { desempenho eficaz no acompanhamento } \\
\text { das metas, bem como no preenchimento } \\
\text { do formulário }\end{array}$ & $\begin{array}{l}\text { - Formar grupos (máximo de } 5 \text { gerentes) } \\
\text { - O grupo terá } 40 \text { minutos para realizar o exercício e } \\
\text { posteriormente um relator do grupo fará a } \\
\text { apresentação em } 10 \text { minutos. }\end{array}$ & $\begin{array}{l}\text { - Cada membro do grupo deverá formalizar quatro reuniões } \\
\text { de acompanhamento, tomando como referencia a(s) meta(s) } \\
\text { negociada(s) na etapa anterior (negociação). }\end{array}$ \\
\hline & $\bullet$ Em grupo & $\begin{array}{l}\text { - Capacitar os gerentes na } \\
\text { operacionalização da etapa de avaliação } \\
\text { do desempenho, bem como no } \\
\text { preenchimento do formulário }\end{array}$ & $\begin{array}{l}\text { - Formar grupos (máximo de } 5 \text { gerentes) } \\
\text { - O grupo terá } 20 \text { minutos para realizar o exercício e } \\
\text { para um relator do grupo fazer a apresentação. }\end{array}$ & $\begin{array}{l}\text { - Cada membro do grupo deverá efetuar a síntese dos } \\
\text { resultados, tomando como referência os padrões de } \\
\text { desempenho da etapa de negociação, bem como os registros } \\
\text { da etapa de acompanhamento. }\end{array}$ \\
\hline
\end{tabular}


Esta análise documental buscou descrever as características formais do curso, relativas à formulação de objetivos instrucionais, à adequação das estratégias instrucionais, à compatibilidade dos exercícios com a natureza e a complexidade dos objetivos instrucionais, ao planejamento das atividades, à seqüência do ensino e às fontes de informação (bibliografia e outros meios), usando como parâmetro o "Roteiro de Análise dos materiais didáticos" (Anexo B).

O programa instrucional do treinamento explicita os objetivos conforme plano das aulas, ver Quadro 1. Observa-se que a descrição dos objetivos instrucionais está abrangente, alguns não estão explícitos e completos, e não foram descritos em termos de comportamentos observáveis e o controle da aprendizagem está centrado no professor.

Quadro 3 - Detalhamento dos objetivos instrucionais do Treinamento

\begin{tabular}{|c|c|c|}
\hline Objetivos específicos & Falha & Objetivo instrucional \\
\hline $\begin{array}{l}\text { - Transmitir conhecimentos } \\
\text { sobre avaliação de } \\
\text { Desempenho; } \\
\text { - Preparar para a correta } \\
\text { operacionalização dos } \\
\text { processos avaliativos da } \\
\text { Instituição. }\end{array}$ & $\begin{array}{l}\text { - O verbo transmitir não } \\
\text { indica uma ação } \\
\text { observável. } \\
\text { - O verbo preparar indica } \\
\text { uma ação observável de } \\
\text { aplicação, no entanto, } \\
\text { quais competências } \\
\text { devam ser desenvolvidas. }\end{array}$ & $\begin{array}{l}\text { - Aplicar os conhecimentos sobre avaliação de } \\
\text { desempenho para outras pessoas; } \\
\text { - Distinguir os processos avaliação existentes } \\
\text { na Instituição; } \\
\text { - Discutir os conhecimentos iniciais dos } \\
\text { processos avaliação da Instituição com outras } \\
\text { pessoas; } \\
\text { - Identificar as fases do GD para fins de } \\
\text { aplicação do programa GD. }\end{array}$ \\
\hline $\begin{array}{l}\text { - Preparar para a correta } \\
\text { operacionalização da fase de } \\
\text { negociação do GD. }\end{array}$ & $\begin{array}{l}\text { O verbo preparar indica } \\
\text { uma ação observável de } \\
\text { aplicação, no entanto, este } \\
\text { verbo não detalha quais } \\
\text { competências devam ser } \\
\text { desenvolvidas pelos } \\
\text { participantes. }\end{array}$ & $\begin{array}{l}\text { - Conhecer definições de objetivos } \\
\text { institucionais e setoriais e noções de } \\
\text { planejamento e de redação; } \\
\text { - Descrever a fase de negociação do programa } \\
\text { de gestão de desempenho; } \\
\text { - Analisar e identificar as competências } \\
\text { necessárias para realização das metas; } \\
\text { - Praticar a operacionalização da fase de } \\
\text { negociação do programa de gestão } \\
\text { desempenho }\end{array}$ \\
\hline \multirow[t]{2}{*}{$\begin{array}{l}\text { - Preparar para a correta } \\
\text { operacionalização das fases de } \\
\text { Acompanhamento e de } \\
\text { Avaliação do GD. }\end{array}$} & \multirow[t]{2}{*}{$\begin{array}{l}\text { - O verbo preparar indica } \\
\text { uma ação observável de } \\
\text { aplicação, no entanto, o } \\
\text { verbo não detalha quais } \\
\text { competências devam ser } \\
\text { desenvolvidas pelos } \\
\text { participantes. }\end{array}$} & $\begin{array}{l}\text { - Conhecer a fase de Acompanhamento e do } \\
\text { programa de gestão de desempenho; } \\
\text { - Planejar entrevista de acompanhamento; } \\
\text { - Dar e receber feedback positivo e negativo; } \\
\text { - Praticar a operacionalização da fase de } \\
\text { acompanhamento; }\end{array}$ \\
\hline & & $\begin{array}{l}\text { - Conhecer a fase de Avaliação do desempenho } \\
\text { do programa de gestão de desempenho; } \\
\text { - Praticar a operacionalização da última fase; } \\
\text { - Descrever as vantagens ao final do processo } \\
\text { de avaliação para os avaliados; } \\
\text { - Esclarecer aos avaliados sobre as } \\
\text { discordâncias na avaliação final do GD que } \\
\text { porventura ocorra. }\end{array}$ \\
\hline
\end{tabular}


Segundo Abbad et al. (2006, p. 294), os objetivos instrucionais "devem explicitar exatamente o que o aprendiz será capaz de fazer ou dizer, após a instrução". Um objetivo instrucional completo é composto por três variáveis: condição - variáveis do ambiente que restringe ou apóiam o acontecimento dos desempenhos esperados; desempenho - combinação de um verbo que indica ação humana observável e de um objeto da ação; e o critério - nível de competência ou do padrão de desempenho esperado. Consta do Quadro 3 uma avaliação e desmembramento dos objetivos instrucionais do treinamento para clarificação dos aspectos referentes à sequiência de objetivos baseadas na aprendizagem.

A natureza do domínio de aprendizagem a que pertence os objetivos do treinamento são pertencentes ao domínio cognitivo com interação aos outros domínios, afetivo e psicomotor, relativos às hierarquias sobre processos cognitivos, ou seja, a classificação de objetivos educacionais conforme a aplicação das taxonomias de Bloom e Simpson, citadas por Abbad et al. (2006) e descrito por Rodrigues Jr. (2006). No que se refere à aprendizagem, o uso de objetivos de ensino possibilita elaborar formas e instrumentos de avaliação válidos e confiáveis conforme citado por Abbad et al. (2006).

Do material instrucional analisado consta bibliografia utilizada para elaboração do curso, bem como referência de autores como sugestão para consultas.

No que se refere ao planejamento das atividades, verifica-se da análise realizada e do disposto no Quadro 1 e 2 que o estabelecimento de sequiência dos conteúdos está de um modo geral adequado visto que há uma ordem seguida para desenvolver o treinamento, baseada nos objetivos. Neste sentido, Abbad et al.(2006) recomenda que os objetivos e os conteúdos do treinamento seja apresentado aos participantes para conhecimento exato das competências que se pretende desenvolver nos treinandos. A carga horária, em vista do conteúdo apresentado e dos exercícios propostos, não é adequada. Sugere-se que haja ampliação da carga horária na ocorrência de outros treinamentos para que o tempo gasto com as atividades práticas e exercícios sejam ampliados, principalmente nas duas últimas aulas (ver Quadro 2).

Os exercícios de fixação propostos são compatíveis com a natureza dos objetivos instrucionais. Ao final, os exercícios de fixação discutidos em conjunto, instrutores e participantes, verificam as soluções propostas. As atividades propostas estimulam os participantes a elaborar o planejamento das metas setoriais, simulação de cada fase da metodologia e seus desdobramentos (ver Quadro 2). Percebe-se que essa dinâmica permite a prática do conteúdo aprendido na aula e restringe-se ao nível de compreensão do conteúdo. Não há no material instrucional analisado a avaliação dos exercícios de fixação. E, também, 
não constou do material instrucional analisado os resultados da avaliação de expectativas um dos procedimentos da primeira aula (ver Quadro 1).

Os textos, definidos no plano de aula (ver Quadro 1) como recursos, poderiam ampliar os conhecimentos sobre o assunto exposto sendo mais um recurso instrucional de acréscimo do conteúdo abordado, ocorre que no material instrucional não há indicativo do momento em que os participantes fizeram uso deles.

A apresentação e organização articulada com o conteúdo programático das apostilas e similares, bem como a qualidade gráfica e quantidade adequada de informação contida nas cópias de slides não estão descritos do material instrucional.

A seguir o Quadro 4 mostra sugestão de um esboço de desenho instrucional, elaborado pela autora desta pesquisa, com base nas análises feitas, para futuros treinamentos sobre este assunto. 
Quadro 4 - Sugestão de desenho instrucional para o Treinamento Gerencial para Aplicação do Programa de Gestão de Desempenho

\begin{tabular}{|c|c|c|c|c|c|}
\hline \multicolumn{6}{|c|}{ TREINAMENTO GERENCIAL PARA APLICAÇÃO DO PROGRAMA DE GESTÃO DE DESEMPENHO } \\
\hline Objetivo do curso & Aulas & Objetivos específicos & Conteúdo & Procedimentos & Recursos \\
\hline \multirow{4}{*}{$\begin{array}{l}\text { Desenvolvimento de } \\
\text { habilidades } \\
\text { necessárias à Gestão } \\
\text { de Desempenho; } \\
\text { Alcance do domínio } \\
\text { por parte dos gerentes } \\
\text { de todas as fases do } \\
\text { processo } \\
\text { sensibilização dos } \\
\text { gerentes quanto á } \\
\text { aceitação e o } \\
\text { envolvimento com o } \\
\text { método avaliativo. }\end{array}$} & $\begin{array}{l}\text { Aula } 1 \\
-4 \mathrm{hs}\end{array}$ & $\begin{array}{l}\text { - Aplicar os conhecimentos sobre avaliação de desempenho; } \\
\text { - Distinguir os processos avaliação da Instituição; } \\
\text { - Discutir os conhecimentos iniciais dos processos avaliação da } \\
\text { Instituição; } \\
\text { - Identificar as fases do GD. }\end{array}$ & $\begin{array}{l}\text { - Importância do processo de } \\
\text { avaliação; } \\
\text { - Os métodos de avaliação da } \\
\text { Instituição: restágio } \\
\text { probatório e GD (histórico, } \\
\text { conceituação, benefícios e } \\
\text { fases. }\end{array}$ & $\begin{array}{l}\text { - Exposição oral dialogada; } \\
\text { - Avaliação de } \\
\text { expectativas; } \\
\text { - Discussão em grupo; } \\
\text { - Folha de exercício } \\
\text { individual }\end{array}$ & $\begin{array}{l}\text { - Canhão de projeção; } \\
\text { - Documentos normativos } \\
\text { GD (Instrução da Reitoria } \\
\text { n. 003/2001 e Manual); } \\
\text { - Texto: "como fazer uma } \\
\text { boa avaliação de } \\
\text { desempenho". } \\
\text { - Bibliografia. }\end{array}$ \\
\hline & $\begin{array}{l}\text { Aula } 2 \\
-4 \mathrm{hs}\end{array}$ & $\begin{array}{l}\text { - Conhecer definições de objetivos institucionais e setoriais e noções de } \\
\text { planejamento e de redação; } \\
\text { - Descrever a fase de negociação do programa de gestão de desempenho; } \\
\text { - Analisar e identificar as competências necessárias para realização das } \\
\text { metas; } \\
\text { - Praticar a operacionalização da fase de negociação do programa de } \\
\text { gestão desempenho; }\end{array}$ & $\begin{array}{l}\text { - Negociação (conceituação; } \\
\text { conhecimentos e } \\
\text { habilidades; } \\
\text { desenvolvimento; análise da } \\
\text { capacitação profissional; e } \\
\text { formalização da negociação } \\
\text { do desempenho - formulário } \\
\text { preenchido). }\end{array}$ & $\begin{array}{l}\text { - Exposição oral dialogada; } \\
\text { - Folha de exercício } \\
\text { individual e em grupo. }\end{array}$ & $\begin{array}{l}\text { • Canhão de projeção; } \\
\text { • Texto: "Maximizando o } \\
\text { Desempenho". }\end{array}$ \\
\hline & $\begin{array}{l}\text { Aula } 3 \\
-4 \text { hs. }\end{array}$ & $\begin{array}{l}\text { - Conhecer a fase de Acompanhamento e do programa de gestão de } \\
\text { desempenho; } \\
\text { - Planejar entrevista de acompanhamento; } \\
\text { - Dar e receber feedback positivo e negativo; } \\
\text { - Praticar a operacionalização da fase de acompanhamento; }\end{array}$ & $\begin{array}{l}\text { - Acompanhamento } \\
\text { (conceituação, } \\
\text { conhecimento e habilidades, } \\
\text { e desenvolvimento); }\end{array}$ & $\begin{array}{l}\text { - Exposição oral dialogada; } \\
\text { - Exercício em grupo }\end{array}$ & $\begin{array}{l}\text { - Canhão de projeção; } \\
\text { - Texto: "Como planejar e } \\
\text { conduzir uma reunião de } \\
\text { acompanhamento"; }\end{array}$ \\
\hline & $\begin{array}{l}\text { Aula } 4 \\
-4 \text { hs. }\end{array}$ & $\begin{array}{l}\text { - Conhecer a fase de Avaliação do desempenho do programa de gestão } \\
\text { de desempenho; } \\
\text { - Praticar a operacionalização da última fase; } \\
\text { - Descrever as vantagens ao final do processo de avaliação para os } \\
\text { avaliados; } \\
\text { - Esclarecer aos avaliados sobre as discordâncias que porventura ocorra. }\end{array}$ & $\begin{array}{l}\text { - Avaliação (definição, } \\
\text { desenvolvimento, } \\
\text { formalização); } \\
\text { - Premiações e progressão por } \\
\text { mérito; } \\
\text { • Consultoria interna }\end{array}$ & $\begin{array}{l}\text { - Exposição oral dialogada; } \\
\text { - Exercício em grupo }\end{array}$ & • Canhão de projeção. \\
\hline
\end{tabular}




\section{b) Avaliação de Reação}

Neste item estão descritos os resultados das avaliações de reações dos participantes ao curso avaliado nesta pesquisa. Os participantes emitiram suas opiniões quanto ao treinamento com base nos 39 itens do questionário "avaliação de reação" (Anexo A), referentes aos seguintes tópicos: programação, apoio ao desenvolvimento do treinamento, aplicabilidade e utilidade, resultado imediatos do curso, expectativas de suporte à transferência; e, quanto ao desempenho do instrutor têm-se os tópicos: desempenho didático, domínio de conteúdo e entrosamento com os treinandos; por último há campo para comentários/críticas/sugestões. A escala utilizada para avaliação é: ruim, insuficiente, regular, bom e ótimo.

As respostas dadas pelos participantes na avaliação de reação foram efetuadas no último dia de treinamento. Do primeiro grupo, no total de 46 participantes, 12 responderam o questionário. Dos 46 participantes do segundo grupo, 20 responderam o questionário de avaliação.

A Tabela 1 exibe a avaliação de reação do curso feita pelos participantes do primeiro em termos de médias e desvios padrões. 
Tabela 1 - Distribuição de reação primeiro grupo

\begin{tabular}{|c|c|c|c|c|}
\hline Quanto à Programação & Válidos & Inválidos & Média & $\begin{array}{l}\text { Desvio } \\
\text { Padrão }\end{array}$ \\
\hline 1 Clareza na definição dos objetivos do treinamento. & 12 & 0 & 4,58 & 0,515 \\
\hline 2 Compatibilidade dos objetivos do treinamento com as suas necessidades e expectativas & 12 & 0 & 4,42 & 0,515 \\
\hline 3 Carga horária programada para as atividades teóricas & 11 & 1 & 4,27 & 0,647 \\
\hline 4 Ordenação do conteúdo programático. & 12 & 0 & 4,75 & 0,452 \\
\hline 5 Carga horária programada para as atividades práticas. & 12 & 0 & 4,33 & 0,651 \\
\hline 6 Carga horária diária. & 9 & 3 & 4,33 & 0,500 \\
\hline 7 Adequação do conteúdo programático aos objetivos do treinamento. & 12 & 0 & 4,67 & 0,492 \\
\hline Apoio ao Desenvolvimento do Treinamento & Válidos & Inválidos & Média & $\begin{array}{l}\text { Desvio } \\
\text { Padrão }\end{array}$ \\
\hline $8 \overline{\text { Qualidade das instalações }}$ & 12 & 0 & 3,33 & 0,985 \\
\hline 9 Qualidade e organização do material didático. & 12 & 0 & 4,33 & 0,492 \\
\hline O Quantidade de material didático distribuído. & 12 & 0 & 4,50 & 0,522 \\
\hline Aplicabilidade e utilidade do treinamento & Válidos & Inválidos & Média & $\begin{array}{l}\text { Desvio } \\
\text { Padrão }\end{array}$ \\
\hline $\begin{array}{l}\text { Utilidade dos conhecimentos e habilidades enfatizados no treinamento para resolução de problemas } \\
\text { de trabalho. }\end{array}$ & 12 & 0 & 4,58 & 0,515 \\
\hline $\begin{array}{l}\text { Possibilidade de ap licação, a curto prazo, dos conhecimentos adquiridos na execução de suas tarefas } \\
\text { no trabalho. }\end{array}$ & 11 & 1 & 4,73 & 0,467 \\
\hline Conveniência da disseminação do treinamento para outros servidores da UnB. & 12 & 0 & 4,33 & 0,888 \\
\hline Resultados do Treinamento & Válidos & Inválidos & Média & $\begin{array}{l}\text { Desvio } \\
\text { Padrão }\end{array}$ \\
\hline $4 \overline{\text { Assimilação do conhecimento transmitido no treinamento. }}$ & 11 & 1 & 4,09 & 1,446 \\
\hline 5 Capacidade de reconhecer as situações de trabalho em que é correto ap licar os novos conhecimentos. & 12 & 0 & 4,50 & 0,522 \\
\hline $\begin{array}{l}5 \text { Probabilidade de melhorar seus níveis de desempenho no trabalho como resultados do uso das novas } \\
\text { habilidades. }\end{array}$ & 12 & 0 & 4,58 & 0,515 \\
\hline Capacidade de transmitir os conhecimentos adquiridos no treinamento a outros servidores da UnB. & 12 & 0 & 4,25 & 0,622 \\
\hline $\begin{array}{l}\text { Probabilidade de promover melhorias nas atividades desenvolvidas pelo seu grupo de trabalho, com } \\
\text { base nas habilidades aprendidas no treinamento. }\end{array}$ & 12 & 0 & 4,50 & 0,522 \\
\hline $\begin{array}{l}\text { Contribuição do treinamento para sua integração com outros servidores da sua área de atuação } \\
\text { profissional. }\end{array}$ & 12 & 0 & 4,08 & 0,669 \\
\hline $\begin{array}{l}\text { Estímulo decorrente do treinamento para ap licar, no trabalho, os conhecimentos e habilidades } \\
\text { aprendidas. }\end{array}$ & 12 & 0 & 4,58 & 0,515 \\
\hline Intenção de aplicar no trabalho os conhecimentos adquiridos no treinamento. & 12 & 0 & 4,67 & 0,492 \\
\hline Suporte Organizacional & Válidos & Inválidos & Média & $\begin{array}{l}\text { Desvio } \\
\text { Padrão }\end{array}$ \\
\hline $\begin{array}{l}\text { Probabilidade de dispor dos instrumentos, materiais, suprimentos, equipamentos e demais recursos } \\
\text { necessários ao uso de novas habilidades. }\end{array}$ & 12 & 0 & 4,08 & 0,669 \\
\hline 3 Oportunidades de praticar as novas habilidades no trabalho. & 12 & 0 & 4,50 & 0,522 \\
\hline $\begin{array}{l}\text { Probabilidade de encontrar, no seu ambiente de trabalho, um clima propício ao uso das habilidades } \\
\text { aprendidas no treinamento. }\end{array}$ & 12 & 0 & 4,25 & 0,754 \\
\hline Desempenho Didático & Válidos & Inválidos & Média & $\begin{array}{l}\text { Desvio } \\
\text { Padrão }\end{array}$ \\
\hline 55 Transmissão dos objetivos do treinamento. & 12 & 0 & 4,92 & 0,289 \\
\hline 6 Sumarização e revisão do conteúdo ensinado. & 12 & 0 & 4,83 & 0,389 \\
\hline 7 Nível de organização seqüencial do conteúdo do treinamento & 12 & 0 & 4,92 & 0,289 \\
\hline $\begin{array}{l}\text { Nível de profundidade com que os temas e assuntos foram abordados, tendo em vista o objetivo do } \\
\text { treinamento. }\end{array}$ & 11 & 1 & 4,55 & 0,522 \\
\hline 9 Ritmo de apresentação dos tópicos. & 12 & 0 & 4,50 & 0,522 \\
\hline 0 Uso de estratégias para motivar os alunos em relação aos temas abordados no treinamento. & 12 & 0 & 4,58 & 0,669 \\
\hline 1 Qualidade da apresentação dos conteúdos e da exemplificação. & 12 & 0 & 4,75 & 0,452 \\
\hline $\begin{array}{l}\text { Uso de estratégias instrucionais (exposições orais, discussões em grupo e similares) em relação à } \\
2 \text { apreensão do conteúdo. }\end{array}$ & 12 & 0 & 4,75 & 0,452 \\
\hline $\begin{array}{l}\text { Uso de recursos instrucionais (quadro de giz, quadro branco, retroprojetor, etc.) em relação à } \\
\text { apreensão do conteúdo. }\end{array}$ & 12 & 0 & 4,50 & 0,522 \\
\hline 4 Qualidade das avaliações de aprendizagem. & 11 & 1 & 4,55 & 0,522 \\
\hline Domínio do conteúdo & Válidos & Inválidos & Média & $\begin{array}{l}\text { Desvio } \\
\text { Padrão }\end{array}$ \\
\hline $5 \overline{\text { Conhecimento dos temas abordados no treinamento. }}$ & 12 & 0 & 4,83 & 0,389 \\
\hline 6 Segurança na transmissão dos conteúdos do treinamento. & 12 & 0 & 4,83 & 0,389 \\
\hline Entrosamento com os treinandos & Válidos & Inválidos & Média & $\begin{array}{l}\text { Desvio } \\
\text { Padrão }\end{array}$ \\
\hline 7 Disposição para esclarecer dúvidas. & 12 & 0 & 4,83 & 0,389 \\
\hline 8 Respeito às idéias manifestadas pelos alunos acerca dos temas abordados no trein & 12 & 0 & 4,83 & 0,389 \\
\hline 9 Estímulo dado aos alunos para manifestarem suas idéias. & 12 & 0 & 4,67 & 0,651 \\
\hline
\end{tabular}

De modo geral, nos quesitos referente a aprendizagem e nas questões referente ao desempenho do instrutor os avaliados consideraram o curso "bom" e "ótimo". 
Tabela 2 - Distribuição das res pos tas de reação segundo grupo

Quanto à Programação

Compatibilidade dos objetivos do treinamento com as suas necessidades e

2 expectativas

3 Carga horária programada para as atividades teóricas

4 Ordenação do conteúdo programático.

5 Carga horária programada para as atividades práticas.

6 Carga horária diária.

7 Adequação do conteúdo programático aos objetivos do treinamento. Apoio ao Desenvolvimento do Treinamento

8 Qualidade das instalações

9 Qualidade e organização do material didático.

10 Quantidade de material didático dis tribuído.

Aplicabilidade e utilidade do treinamento

11 resolução de problemas de trabalho.

Possibilidade de aplicação, a curto prazo, dos conhecimentos adquiridos na 12 execução de suas tarefas no trabalho.

13 Conveniência da disseminação do treinamento para outros servidores da UnB.

\section{Resultados do Treinamento}

14 Assimilação do conhecimento trans mitido no treinamento.

Capacidade de reconhecer as situações de trabalho em que é correto aplicar os 15 novos conhecimentos.

Probabilidade de melhorar seus níveis de desempenho no trabalho como

16 resultados do uso das novas habilidades.

Capacidade de transmitir os conhecimentos adquiridos no treinamento a outros 17 servidores da UnB.

Probabilidade de promover melhorias nas atividades desenvolvidas pelo seu

18 grupo de trabalho, com base nas habilidades aprendidas no treinamento.

Contribuição do treinamento para sua integração com outros servidores da sua

19 área de atuação profissional.

Estímulo decorrente do treinamento para aplicar, no trabalho, os conhecimentos

20 e habilidades aprendidas.

21 Intenção de aplicar no trabalho os conhecimentos adquiridos no treinamento.

$$
\text { Suporte Organizacional }
$$

Probabilidade de dis por dos instrumentos, materiais, suprimentos, equipamentos

22 e demais recursos necessários ao uso de novas habilidades.

23 Oportunidades de praticar as novas habilidades no trabalho.

Probabilidade de encontrar, no seu ambiente de trabalho, um clima propício ao

24 uso das habilidades aprendidas no treinamento.

\begin{tabular}{|c|c|c|c|c|}
\hline Desempenho Didático & Válidos & Inválidos & Média & $\begin{array}{l}\text { Desvio } \\
\text { Padrão } \\
\end{array}$ \\
\hline 25 Transmissão dos objetivos do treinamento. & 20 & 0 & 4,70 & 0,470 \\
\hline 26 Sumarização e revisão do conteúdo ensinado. & 20 & 0 & 4,55 & 0,510 \\
\hline 27 Nível de organização seqüencial do conteúdo do treinamento & 20 & 0 & 4,75 & 0,444 \\
\hline $\begin{array}{l}\text { Nível de profundidade com que os temas e assuntos foram abordados, tendo em } \\
28 \text { vista o objetivo do treinamento. }\end{array}$ & 20 & 0 & 4,55 & 0,510 \\
\hline 29 Ritmo de apresentação dos tópicos. & 20 & 0 & 4,45 & 0,510 \\
\hline $\begin{array}{l}\text { Uso de estratégias para motivar os alunos em relação aos temas abordados no } \\
30 \text { treinamento. }\end{array}$ & 20 & 0 & 4,60 & 0,503 \\
\hline 31 Qualidade da apresentação dos conteúdos e da exemplificação. & 20 & o & 4,50 & 0,513 \\
\hline $\begin{array}{l}\text { Uso de estratégias instrucionais (exposições orais, discussões em grupo e } \\
32 \text { similares) em relação à apreensão do conteúdo. }\end{array}$ & 20 & 0 & 4,65 & 0,489 \\
\hline $\begin{array}{l}\text { Uso de recursos instrucionais (quadro de giz, quadro branco, retroprojetor, etc.) } \\
33 \text { em relação à apreensão do conteúdo. }\end{array}$ & 20 & 0 & 4,60 & 0,503 \\
\hline 34 Qualidade das avaliações de aprendizagem. & 20 & 0 & 4,25 & 1,118 \\
\hline Domínio do conteúdo & Válidos & Inválidos & Média & $\begin{array}{l}\text { Desvio } \\
\text { Padrão }\end{array}$ \\
\hline $35 \overline{\text { Conhecimento dos temas abordados no tre }}$ & 20 & 0 & 4,50 & 0,513 \\
\hline 36 Segurança na transmissão dos conteúdos do treinamento. & 20 & 0 & 4,55 & 0,510 \\
\hline Entros amento com os treinandos & Válidos & Inválidos & Média & $\begin{array}{l}\text { Desvio } \\
\text { Padrão }\end{array}$ \\
\hline $37 \overline{\text { Disposição para esclarecer dúvidas. }}$ & 20 & 0 & 4,80 & 0,410 \\
\hline $\begin{array}{l}\text { Respeito às idéias manifestadas pelos alunos acerca dos temas abordados no } \\
38 \text { treinamento. }\end{array}$ & 20 & 0 & 4,80 & 0,410 \\
\hline 39 Estímulo dado aos alunos para manifestarem suas idéias. & 20 & 0 & 4,80 & 0,410 \\
\hline
\end{tabular}

Nota-se conforme Tabela 2 que, de modo geral, o segundo grupo teve percepção parecida ao primeiro grupo quanto aos quesitos avaliados. A maioria dos ex-participantes considerou o curso e o desempenho do instrutor "bom" ou "ótimo". 
A última parte do questionário "avaliação de reação", destinada ao registro de comentários, críticas e sugestões, possibilitou aos ex-participantes espaço para o registro de opiniões e contribuições para a melhoria do treinamento gerencial.

As respostas dos respondentes do primeiro grupo estão descritas logo em seguida:

"Carga horária do curso seja em tempo maior, ou seja, 2hs de curso ao dia." (1)

"Curso satisfatório e há expectativa de novos cursos." (1)

"Proporcionar cursos semelhantes com freqüência." (1)

"SRH/FUB deveria estar aplicando cursos no HUB, para os funcionários terem mais conhecimento e entretenimento para enriquecimento dos servidores." (1)

As respostas dos respondentes do segundo grupo foram:

"Encontrar condições no ambiente de trabalho para proceder uma avaliação mais digna e justa." (1)

"Como foi sugerido por colegas do curso, seria interessante convocar os docentes para esse tipo de treinamento." (1)

"Levar o curso aos departamentos e faculdades; divulgar importância para o servidor e para a instituição; oferecer cursos que realmente venham de encontro às necessidades diárias e cotidianas...melhorar as competências dos gerente todos..." (1)

"Explanar o oferecimento do curso para a comunidade da UnB e aumentar a carga horária." (1)

"Redução da carga horária diária e aumento do número de dias para facilitar liberação dos encargos cotidianos." (1)

"Que todos os anos tenham este curso." (1)

"Professora muito obrigada pela atenção. Desculpe alguma falha minha." (1)

Os dados apresentados na Tabela 1 e 2, bem como as comentários e sugestões feitas pelos respondentes demonstram que o curso foi satisfatório seja quanto aos procedimentos instrucionais, a instrutoria e ao aprendizado o que reforçam os resultados em outras pesquisas Abbad (1999) e Alves, Pasquali e Pereira (1999).

A seguir são apresentados os dados da aplicação do programa de gestão de desempenho - GD pelos participantes que tiveram 02 ou mais presença no curso. 


\subsection{O Programa de Gestão de Desempenho - GD na prática}

O Relatório de aplicação do GD do período de avaliação 2006-2007 apresenta a análise da aplicação realizada pelos gerentes, inclusive dos ex-participantes do treinamento pesquisado. (Universidade de Brasília, 2006).

Do total de 92 ex-participantes integrantes da lista de freqüência do curso, 14 do primeiro grupo e 25 do segundo grupo freqüentaram assiduamente o treinamento são considerados, a princípio, capacitados para a aplicação do GD.

Os 39 ex-participantes que concluíram o curso foram objeto de estudo para verificação da aplicação do GD na prática. Os outros 53 convocados que não compareceram ao treinamento poderão ser analisados em pesquisas futuras, caso estejam no exercício de função gerencial.

O Quadro 5 apresenta as informações referentes a operacionalização do GD, definidas nas normas e constantes do Manual do GD.

Quadro 5: Informações sobre a operacionalização do GD

\begin{tabular}{|c|c|}
\hline \multirow[t]{2}{*}{$\begin{array}{ll}\text { Negociação } & \text { do } \\
\text { desempenho } & \end{array}$} & $\begin{array}{l}\text { - No mês de março de cada ano; } \\
\text { - Reunião, em conjunto, gerente e colaborador; } \\
\text { - Registro das metas (atividades a serem realizadas durante o ciclo mais os padrões de } \\
\text { desempenho - prazo, qualidade e quantidade); } \\
\text { - Análise da Capacitação (competências necessárias para realização das metas; } \\
\text { Competências gerenciais (Liderança, Relacionamento Interpessoal, Comunicação, } \\
\text { Gerência Participativa, Orientação para resultados, Tomada de decisão, } \\
\text { Comprometimento, Administração de Conflitos, Desenvolvimento de pessoas, } \\
\text { Orientação para qualidade, Planejamento e Conhecimento técnico); Competências } \\
\text { individuais (conhecimento do trabalho, relacionamento interpessoal, comunicação, } \\
\text { organização, cooperação, responsabilidade, comprometimento, motivação, } \\
\text { concentração, iniciativa e criatividade); } \\
\text { - Recomendações (treinamento no trabalho; cursos/seminário; leituras; acompanhamento } \\
\text { psicossocial; orientações e outras recomendações) pertinentes ao desenvolvimento das } \\
\text { competências assinaladas. } \\
\text { Data e assinatura do gerente e colaborador. }\end{array}$ \\
\hline & - Data/Assinatura do Termo de Ciência e Comprometimento \\
\hline \multirow[t]{2}{*}{$\begin{array}{l}\text { Acompanhamento } \\
\text { do desempenho }\end{array}$} & $\begin{array}{l}\text { - No mínimo } 2 \text { (duas) reuniões de acompanhamento; } \\
\text { - Resultados Alcançados; } \\
\text { - Ações a Implementar; } \\
\text { - Data e assinatura do gerente e colaborador. }\end{array}$ \\
\hline & - $\quad$ Proposta de Melhoria \\
\hline \multirow[t]{4}{*}{$\begin{array}{ll}\text { Avaliação } & \text { do } \\
\text { Desempenho } & \end{array}$} & $\begin{array}{l}\text { - Registro dos Resultados Alcançados (comparação entre o negociado e o alcançado); } \\
\text { - Registro da Síntese dos Resultados } \\
\text { - Registro da classificação no Relatório Final do desempenho; } \\
\text { - Data e assinatura do gerente e colaborador. }\end{array}$ \\
\hline & - Pontuação Consensual dos indicadores desempenho \\
\hline & - Síntese dos resultados \\
\hline & - Relatório final desempenho \\
\hline
\end{tabular}

Fonte: Manual do Programa de Gestão de Desempenho (Universidade de Brasília, 2001) 
Com base nestas informações foi realizada a análise da aplicação do GD feita por cada um dos ex-paticipantes. O Quadro 6 mostra os resultados das análises da aplicação do Programa pelo primeiro grupo.

Quadro 6 - Resultados da análise da aplicação do GD pelos ex-participantes do primeiro grupo

\begin{tabular}{|c|c|c|c|c|c|}
\hline \multicolumn{6}{|c|}{ Primeiro Grupo } \\
\hline & & $\begin{array}{l}\text { Total } \\
\text { participante } \\
\text { que fizeram } \\
\text { CERTO }\end{array}$ & $\begin{array}{l}\text { Total } \\
\text { participante } \\
\text { que fizeram } \\
\text { ERRADO }\end{array}$ & $\begin{array}{l}\text { Total } \\
\text { participante } \\
\text { que } \mathrm{N} \tilde{\mathrm{A} O} \\
\text { fizeram }\end{array}$ & $\begin{array}{l}\text { Total } \\
\text { participante } \\
\text { SEM } \\
\text { PRESENÇ } \\
\text { A CURSO }\end{array}$ \\
\hline $\begin{array}{l}\text { Negociação do } \\
\text { desempenho }\end{array}$ & $\begin{array}{l}\text { Data/Assinatura do Termo de } \\
\text { Ciência e Comprometimento }\end{array}$ & 4 & 5 & 5 & 30 \\
\hline $\begin{array}{l}\text { Acompanhamento } \\
\text { do desempenho }\end{array}$ & Proposta de melhoria & 6 & 3 & 5 & 30 \\
\hline \multirow{3}{*}{$\begin{array}{l}\text { Avaliação do } \\
\text { desempenho }\end{array}$} & $\begin{array}{l}\text { Pontuação Consensual dos } \\
\text { indicadores desempenho }\end{array}$ & 8 & 1 & 5 & 30 \\
\hline & Síntese dos resultados & 8 & 1 & 5 & 30 \\
\hline & Relatório final desempenho & 9 & 0 & 5 & 30 \\
\hline
\end{tabular}

Fonte: Dados da Pesquisa

Dos ex-participantes que tiveram presença integral ao curso, percebe-se que 05 não aplicaram o processo de avaliação em seu ambiente de trabalho.

Os que aplicaram a metodologia, 04 fizeram corretamente negociação do desempenho esperado no período definido no Manual do GD, ou seja, no mês de março de cada ano e 05 fizeram erradas. Percebe-se, também, que, 06 destes ex-participantes acompanharam o desempenho dos avaliados propondo melhoria do desempenho quanto a treinamento, desenvolvimento do colaborador e condições de trabalho. E que, a maioria, ou seja, 08 fizeram de forma certa a pontuação consensual dos indicadores, o preenchimento da síntese dos resultados e do relatório final avaliação.

O Quadro 7 mostra os resultados das análises da aplicação do Programa pelo segundo grupo, no qual 23 não tiveram presença no curso e dos que tiveram 
Quadro 7 - Resultados análise da aplicação do programa de gestão de desempenho segundo grupo

\begin{tabular}{|c|c|c|c|c|c|}
\hline \multicolumn{6}{|c|}{ Segundo Grupo } \\
\hline & & $\begin{array}{l}\text { Total } \\
\text { Participante } \\
\text { que fizeram } \\
\text { CERTO }\end{array}$ & $\begin{array}{l}\text { Total } \\
\text { participante } \\
\text { que fizeram } \\
\text { ERRADO }\end{array}$ & $\begin{array}{l}\text { Total } \\
\text { participante } \\
\text { que NÃOO } \\
\text { fizeram }\end{array}$ & $\begin{array}{c}\text { Total } \\
\text { participante } \\
\text { SEM } \\
\text { PRESENÇA } \\
\text { CURSO }\end{array}$ \\
\hline \multirow{5}{*}{$\begin{array}{l}\text { Negociação } \\
\text { do } \\
\text { desempenho }\end{array}$} & No mês de março de cada ano; & 1 & 18 & 6 & 23 \\
\hline & $\begin{array}{l}\text { Registro das metas (atividades a } \\
\text { serem realizadas durante o ciclo, } \\
\text { descrição no infinitivo) }\end{array}$ & 13 & 6 & 6 & 23 \\
\hline & $\begin{array}{l}\text { Registro dos padrões de } \\
\text { desempenho - prazo (em tempo), } \\
\text { qualidade (em \%) e quantidade } \\
\text { (em volume) }\end{array}$ & 12 & 7 & 6 & 23 \\
\hline & $\begin{array}{l}\text { Análise da Capacitação } \\
\text { (competências necessárias para } \\
\text { realização das metas - gerenciais } \\
\text { individuais, conforme o caso). }\end{array}$ & 19 & 0 & 6 & 23 \\
\hline & $\begin{array}{l}\text { Recomendações (treinamento no } \\
\text { trabalho; cursos/seminário; } \\
\text { leituras; acompanhamento } \\
\text { psicossocial; orientações e outras } \\
\text { recomendações) pertinentes ao } \\
\text { desenvolvimento das } \\
\text { competências assinaladas. }\end{array}$ & 19 & 0 & 6 & 23 \\
\hline \multirow{3}{*}{$\begin{array}{l}\text { Acompanham } \\
\text { ento do } \\
\text { desempenho }\end{array}$} & $\begin{array}{l}\text { No mínimo } 2 \text { (duas) reuniões de } \\
\text { acompanhamento }\end{array}$ & 9 & 10 & 6 & 23 \\
\hline & Resultados Alcançados & 6 & 13 & 6 & 23 \\
\hline & Ações a Implementar; & 3 & 16 & 6 & 23 \\
\hline \multirow[t]{4}{*}{$\begin{array}{l}\text { Avaliação do } \\
\text { Desempenho }\end{array}$} & $\begin{array}{l}\text { Registro dos Resultados } \\
\text { Alcançados (comparação entre o } \\
\text { negociado e o alcançado); }\end{array}$ & 17 & 2 & 6 & 23 \\
\hline & $\begin{array}{llll}\text { Registro da } & \text { Síntese } & \text { dos } \\
\text { Resultados } & & & \\
\end{array}$ & 18 & 1 & 6 & 23 \\
\hline & $\begin{array}{l}\text { Registro da classificação no } \\
\text { Relatório Final do desempenho; }\end{array}$ & 18 & 1 & 6 & 23 \\
\hline & $\begin{array}{l}\text { Data e assinatura do gerente e } \\
\text { colaborador. }\end{array}$ & 19 & 0 & 6 & 23 \\
\hline
\end{tabular}

Fonte: Dados da Pesquisa

No segundo grupo, percebe-se que:

- os ex-participantes não realizaram a negociação do desempenho no mês de março do período de avaliação;

- que, a maioria não fez os acompanhamentos do desempenho conforme a metodologia, ou seja, reunir-se com o colaborador para verificação dos resultados ou de implementação de ações preventivas;

- que na última fase, avaliação final do desempenho, os ex-participantes fizeram de forma adequada o preenchimento dos Resultados Alcançados, da Sintese dos Resultados bem como da classificação no relatório final do desempenho. 
Pelos resultados apresentados pode-se constatar que um número significativo dos gerentes treinados que aplicaram o programa de gestão de desempenho-GD cometeu erros na operacionalização, ou seja, o processo de avaliação não é utilizado nos moldes da norma e procedimentos técnicos definidos para a aplicação do processo, talvez devido a fatores externo ao ambiente de treinamento, ou mesmo a variáveis do dia a dia do gerente.

Será necessária a realização de pesquisas futuras para investigar, os motivos pelos quais isto está ocorrendo, assim como para conhecer as razões que levaram vários gerentes a não realizar a avaliação. 


\subsection{Comparação entre o desenho instrucional, a avaliação de reação e o resultado da GD na prática.}

A partir dos dados da avaliação de reação foi possível observar a partir das médias, que os treinandos consideraram o curso, em todos os aspectos avaliados, como bom ou ótimo, com apenas algumas ressalvas apontadas por alguns treinandos. As sugestões citadas pelos treinandos são referentes à expansão da carga horária, a participação da comunidade universitária no curso, a divulgação da importância da GD para o servidor e a instituição, a realização de outros cursos que propiciem o desenvolvimento das competências gerenciais.

Já em relação o desenho instrucional, os objetivos estabelecidos (transmitir conhecimentos sobre avaliação de desempenho; preparar para a correta operacionalização dos processos avaliativos da instituição) estavam direcionados à atuação do instrutor e não com foco nos treinandos, o que, eventualmente pode justificar os erros identificados (negociação do desempenho não realizada no período disposto na norma e não há indícios que os acompanhamentos tenham acontecido por meio de reuniões, entre avaliador e avaliando) com o preenchimento do formulário de avaliação do desempenho. Observa-se que na análise da qualidade e pertinência dos resultados dos exercícios não há evidências de quais foram os resultados obtidos pelos ex-participantes e se houve ou não o feedback dos resultados pelo instrutor. No que se refere aos textos utilizados nas aulas seria pertinente, em pesquisas futuras, também, a análise da qualidade dos textos, bem como sua pertinência para o aprendizado.

Há porém, necessidade de novas pesquisas para analisar essas relações de modo mais aprofundado. 


\section{6 - CONSIDERAÇÕES FINAIS}

O objetivo desta pesquisa foi identificar a existência de impacto do treinamento gerencial sobre a aplicação e resultados do programa de gestão de desempenho-GD após a conclusão do treinamento. Os resultados obtidos tiveram como base a percepção dos exparticipantes dos dois cursos realizados em 2006, que responderam, no último dia de treinamento, a um questionário sobre a satisfação do curso. Realizou-se também nesta pesquisa análise do desenho instrucional do treinamento, bem como os resultados da aplicação do GD pelos ex-participantes. Os resultados foram analisados com a utilização do programa SPSS e pelo Microsoft Excel 2002.

As principais conclusões foram: 1) confirmação da necessidade de treinamento para os avaliadores de um sistema de gestão de desempenho; 2) o planejamento do desenho instrucional apresenta alguns problemas que devem ser objeto de modificação, para buscar assegurar um melhor resultado de treinamentos futuros; 3) a satisfação de treinandos com um treinamento não assegura o correto uso dos conhecimentos abordados no curso; 4) o treinamento não contribuiu adequadamente para o alcance de resultados das avaliações de desempenho procedidas pelos participantes. Além disso, esta pesquisa propiciou acréscimo de conhecimentos sobre os assuntos abordados.

Esses resultados são corroborados pelo relatório de pesquisa realizado por Odelius, em 2000. O relatório indica que inúmeros aspectos interferem em um sistema de avaliação de desempenho, entre eles o treinamento dos avaliadores e que todas as instituições pesquisadas atenderam a este aspecto indicativo de sucesso de um processo de avaliação. Ocorre que os sistemas não atendem às necessidades das instituições e que os resultados do treinamento dos avaliadores, não é suficiente para que na prática os avaliadores procedam a avaliação de desempenho de seus colaboradores de acordo com as normas técnicas estabelecidas (ODELIUS, 2000) .

As limitações desta pesquisa se referem ao fato de ter sido analisado apenas um dos treinamentos realizados e de não ter sido feito um pré-teste quanto aos conhecimentos que os treinandos detinham antes do treinamento e/ou não ter sido efetuada a análise de resultados da aplicação do processo de avaliação antes dos avaliadores participarem do treinamento. 
Para aprofundar o entendimento dos impactos do treinamento e das variáveis que influenciam os resultados do programa de gestão de desempenho, sugere-se que sejam realizadas outras pesquisas, que abordem:

- no desenho instrucional os resultados dos exercícios propostos, bem como o uso dos textos que foram sugeridos no plano de aula;

- ao ambiente em que o participante está inserido e o impacto do treinamento no trabalho;

- ao impacto do treinamento em profundidade no trabalho relacionando as variáveis: satisfação com o treinamento e a falta de suporte à transferência;

- ao perfil gerencial predominante na Instituição.

Adicionalmente, recomenda -se que haja treinamento de avaliados sobre o programa de gestão de desempenho com o objetivo esclarecê-los quanto ao seu papel neste processo. 


\section{REFERÊNCIAS}

ABBAD, G. S. Sistemas de avaliação de desempenho: opinião de avaliadores e avaliados. Dissertação de Mestrado. Brasília: Universidade de Brasília, Instituto de Psicologia. (1991)

ABBAD, G. S. Medidas de avaliação de procedimentos, processos e apoio instrucionais em TD\&E. In: BORGES-ANDRADE, Jairo Eduardo; ABBAD, Gardênia da Silva; MOURÃO, Luciana. (Org.). Treinamento, desenvolvimento e educação em organizações do trabalho: fundamentos para a gestão de pessoas. Porto Alegre - RS, 2006, v. 1, Cap. 22. p. 443-468.

ABBAD, G.S.; ZERBINI, T; CARVALHO, R. S.; MENESES, P. P. M. Planejamento instrucional em TD\&E. In: BORGES-ANDRADE, Jairo Eduardo; ABBAD, Gardênia da Silva; MOURÃO, Luciana. (Org.). Treinamento, desenvolvimento e educação em organizações do trabalho: fundamentos para a gestão de pessoas. Porto Alegre - RS, 2006, v. 1, Cap. 15. p. 289-321.

ABBAD, G.S.; BORGES-ANDRADE, J.E. Aprendizagem humana em organizações de trabalho. In: José Carlos Zanelli, Jairo Eduardo Borges-Andrade e Antonio Virgílio Bittencourt Bastos (Org.). Psicologia, organizações e trabalho no Brasil. Porto Alegre - RS, Artmed, cap. 7, p. 237-275, 2004.

ABBAD, G. S., NOGUEIRA, R. e WALTER, A. M.. Abordagens instrucionais em planejamento de TD\&E. In: BORGES-ANDRADE, Jairo Eduardo; ABBAD, Gardênia da Silva; MOURÃO, Luciana. (Org.). Treinamento, desenvolvimento e educação em organizações do trabalho: fundamentos para a gestão de pessoas. Porto Alegre - RS, Artemed. 2006a, v. 1,. Cap. 13. Pág. 255-281.

BRANDÃO, H. P., GUIMARÃES, T. A. Gestão de Competências e Gestão de Desempenho: tecnologias distintas ou instrumentos de um mesmo construto? In: Revista de Administração de Empresas da FGV. São Paulo, v. 41, n. 1, p. 8-15, jan./Mar. 2001.

BORGES-ANDRADE, J. E. Avaliação integrada e somativa em TD\&E In: BORGESANDRADE, Jairo Eduardo; ABBAD, Gardênia da Silva; MOURÃO, Luciana. (Org.). Treinamento, desenvolvimento e educação em organizações do trabalho: fundamentos para a gestão de pessoas. Porto Alegre - RS, Artemed. 2006, v. 1,. Cap. 17. Pág. 343-358.

CARVALHO, R. S. e ABBAD, G. Avaliação de Treinamento a Distância: Reação, Suporte à Transferência e Impactos no Trabalho. Revista de Administração Contemporânea. v. 10, n. 1, Jan/Mar, 2006: 95-116.

DEPIERI, M. A. Impacto de Educação corporativa, educação continuada em processos educativos - FORFOR. Dissertação apresentada ao Programa de Pós-Graduação em Administração da Universidade de Brasília, como requisito parcial à obtenção de Grau de Mestrre em Gestão Social e trabalho. Brasília, DF, 2006. 
FREITAS, H. et al. O método de pesquisa survey. Revista de Administração. São Paulo, v. 25, n. 3, p. 105-112, jul/set., 2000.

FREITAS, I. A. e BORGES-ANDRADE, J. E.. Efeitos de Treinamento nos Desempenhos Individual e Organizacional. Revista de Administração de Empresas. Número 3. Volume 44. pág. 44-56. JUL./SET. 2004. http://www.rae.com.br/rae/index.cfm?FuseAction=Artigo \&ID=2197\&Secao=GEST\%20REL $\&$ Volume $=44 \&$ Numero=3\&Ano=2004 acessado em 08/02/2008.

GÜNTHER, H. Desenvolvimento de instrumento par levantamento de dados (survey). In: PASQUALI. L. (Org.). Teoria e métodos de medida em ciências do comportamento. Brasília: UnB-INEP, 1996. cap. 15, p. 387-403.

LAKATOS, E. M., MARCONI, M. A. M.. Fundamentos de metodologia científica. 3 ed. rev.e ampl.- São Paulo: Atlas, 1991.

LUCENA, M. D. S. Avaliação de desempenho: métodos e acompanhamento. São Paulo, McGraw-Hill do Brasil, 1977.

M. D. S. Planejamento estratégico e gestão do desempenho para resultados. São Paulo, Atlas, 2004.

MARRAS, J. P. Administração de recursos humanos: do operacional ao estratégico. 3 ed., São Paulo, Futura, 2000.

ODELIUS, C. C. Experiências de avaliação de desempenho na Administração Pública Federal. Pesquisa ENAP. Cadernos ENAP n. 19, 96p, Brasília, 2000.

OLIVEIRA-CASTRO, G. A., LIMA, G. B. C, VEIGA, M. R. M.. Implantação de um sistema de avaliação de desempenho: métodos e estratégias. Revista de Administração, São Paulo, v. 31, n. 3, p. 38-52, julho/setembro, 1996.

OLIVEIRA-CASTRO, G. A. Um modelo integrado de avaliação do impacto do treinamento no trabalho - IMPACT. Tese de Doutorado. Universidade de Brasília, Brasília, DF, 1999.

PANTOJA, M.J., BORGES-ANDRADE, J. (2002). Uma abordagem Multinível para o Estudo da Aprendizagem e Transferência nas Organizações. [Texto Completo]. Em: Associação Nacional dos Programas de Pós-Graduação em Administração, 26 Encontro Nacional da ANPAD. (Texto em CD-ROM). Salvador: Autor.

PANTOJA, M. J. et al. Valores, suporte psicossocial e impacto do treinamento no trabalho. Estudos de Psicologia 2005, 10(2), 255-265. 
PILATI, R. História e importância de TD\&E. In: BORGES-ANDRADE, Jairo Eduardo; ABBAD, Gardênia da Silva; MOURÃO, Luciana. (Org.). Treinamento, desenvolvimento e educação em organizações do trabalho: fundamentos para a gestão de pessoas. Porto Alegre - RS, Artemed. 2006a, v. 1,. Cap. 08. Pág. 159-176.

PILATI, R. e BORGES-ANDRADE, J. E. Construção de medidas e delineamentos em avaliação de TD\&E. In: BORGES-ANDRADE, Jairo Eduardo; ABBAD, Gardênia da Silva; MOURÃ̃, Luciana. (Org.). Treinamento, desenvolvimento e educação em organizações do trabalho: fundamentos para a gestão de pessoas. Porto Alegre - RS, Artemed. 2006a, v. 1, Cap. 18. Pág. 359-384.

PINHEIRO, M. L. M. Avaliação de desempenho no setor público: problemas e perspectivas. Relatório interno de pesquisa. Cadernos ENAP. n. 3, Brasília, DPD - Diretoria de Pesquisa e Difusão. Brasília, Nov./1996.

RODRIGUES JR., J. F. Taxonomias de objetivos em TD\&E. In.. BORGES-ANDRADE, Jairo Eduardo; ABBAD, Gardênia da Silva; MOURÃO, Luciana. (Org.) Treinamento, desenvolvimento e educação em organizações do trabalho: fundamentos para a gestão de pessoas. Capítulo 14. Porto Alegre - RS, 2006, v. 1, p. 282-287.

TAMAYO, N., ABBAD, G. Autoconceito Profissional e Suporte à Transferência e Impacto do Treinamento no Trabalho. Enanpad 2002.

UNIVERSIDADE DE BRASILIA. Secretaria de Recursos Humanos. Sistema de Gestão de Desempenho. Material de Apoio 1, 2 e 3. Brasília, DF. [s.n.] 3v. 1997.

UNIVERSIDADE DE BRASÍLIA. Secretaria de Recursos Humanos. Gerência de Desempenho Funcional. Material instrucional do Treinamento Gerencial e Relatório do $7^{\mathbf{0}}$ Ciclo do GD - Aplicação e Capacitação. Brasília, DF. [s.n.](2006).

VARGAS, M. R. M. Treinamento e Desenvolvimento: reflexões sobre seus métodos. Revista de Administração, São Paulo, v. 31, n. 2, p. 126-136, abr./jun. 1996.

VARGAS, M. R. M.; ABBAD, G. S. Bases conceituais em treinamento, desenvolvimento e educação - TD\&E.. In. Treinamento, desenvolvimento e educação em organizações do trabalho: fundamentos para a gestão de pessoas / [autores] Jairo E. Borges-Andrade, Gardênia da Silva Abbad, Luciana Mourão; [colaboradores] Acileide Cristiane F. Coelho... [et al.]. Porto Alegre: Artmed, 2006. 576 p.: Il. Cap. 7. Pág. 137-158.

VERGARA, S. C. Projetos e relatórios de pesquisa em administração. 5. Ed. São Paulo: Atlas, 2004.

ZERBINI, T. Estratégias de Aprendizagem, Reações aos Procedimentos de um curso via Internet, Reações ao Tutor e Impacto do Treinamento no Trabalho. Dissertação 
apresentada ao Instituto de Psicologia da Universidade de Brasília como requisito parcial para a obtenção do grau de Mestre em Ciências - Psicologia. Brasília. 2003. 


\section{ANEXO A}

\begin{tabular}{|c|c|c|c|c|c|}
\hline \multicolumn{6}{|c|}{$\begin{array}{l}\text { AVALIAÇÃO DO MODULO PELO SERVIDOR } \\
\text { QUESTIONÁRIO - AVALIAÇÃO DE REAÇÃO }\end{array}$} \\
\hline \multicolumn{6}{|c|}{\begin{tabular}{l|l} 
QUESTIONARIO - AVALIAÇAO DE REAÇAO \\
\end{tabular}} \\
\hline \multicolumn{6}{|l|}{ Nome Completo: } \\
\hline \multicolumn{6}{|l|}{ Forma de Contratação: $\quad$ ( )Quadro $\quad$ ( ) Extra-quadro } \\
\hline \multicolumn{6}{|c|}{$\begin{array}{l}\text { Faixa etária: } \\
\text { ( ) } 18 \text { a } 25 \text { anos ( ) } 26 \text { a } 33 \text { anos ( ) } 34 \text { a } 41 \text { anos ( ) } 42 \text { a } 49 \text { anos ( ) } 50 \text { anos em diante }\end{array}$} \\
\hline \multicolumn{6}{|l|}{ Sexo: ( ) Masculino ( ) Feminino } \\
\hline \multicolumn{6}{|c|}{$\begin{array}{l}\text { Orientações Gerais } \\
\text { Caro Cursando, } \\
\text { Este questionário tem como objetivo coletar dados sobre diferentes aspectos acerca da disciplina que você acabou de } \\
\text { participar, a fim de que seja possível o contínuo aprimoramento dos cursos do Procap. } \\
\text { As informações prestadas por você serão sigilosas. Por favor, responda todos os itens do questionário com atenção e } \\
\text { cuidado. Desde já agradecemos a sua colaboração. } \\
\text { Para responder, você deverá marcar com um "X" a opção que melhor expressa sua avaliação do curso. }\end{array}$} \\
\hline QUANTO Ã PROGRAMAÇÃO & Ruim & Insuficiente & Regular & Bom & Ótimo \\
\hline 1.Clareza na definição dos objetivos do treinamento. & & & & & \\
\hline $\begin{array}{l}\text { 2.Compatibilidade dos objetivos do treinamento com as suas } \\
\text { necessidades e expectativas }\end{array}$ & & & & & \\
\hline 3.Carga horária programada para as atividades teóricas & & & & & \\
\hline 4.Ordenação do conteúdo programático. & & & & & \\
\hline 5.Carga horária programada para as atividades práticas. & & & & & \\
\hline 6.Carga horária diária. & & & & & \\
\hline $\begin{array}{l}\text { 7.Adequação do conteúdo programático aos objetivos do } \\
\text { treinamento. }\end{array}$ & & & & & \\
\hline APOIO AO DESENVOLVIMENTO DO TREINAMENTO & Ruim & Insuficiente & Regular & Bom & Ótimo \\
\hline 8.Qualidade das instalações & & & & & \\
\hline 9.Qualidade e organização do material didático. & & & & & \\
\hline 10.Quantidade de material didático distribuído. & & & & & \\
\hline APLICABILIDADE E UTILIDADE DO TREINAMENTO & Ruim & Insuficiente & Regular & Bom & Ótimo \\
\hline $\begin{array}{l}\text { 11.Utilidade dos conhecimentos e habilidades enfatizados no } \\
\text { treinamento para resolução de problemas de trabalho. }\end{array}$ & & & & & \\
\hline $\begin{array}{l}\text { 12.Possibilidade de aplicação, a curto prazo, dos conhecimentos } \\
\text { adquiridos na execução de suas tarefas no trabalho. }\end{array}$ & & & & & \\
\hline $\begin{array}{l}\text { 13.Conveniência da disseminação do treinamento para outros } \\
\text { servidores.. }\end{array}$ & & & & & \\
\hline RESULTADOS DO TREINAMENTO & Ruim & Insuficiente & Regular & Bom & Ótimo \\
\hline 14.Assimilação do conhecimento transmitido no treinamento. & & & & & \\
\hline $\begin{array}{l}\text { 15.Capacidade de reconhecer as situações de trabalho em que é } \\
\text { correto aplicar os novos conhecimentos. }\end{array}$ & & & & & \\
\hline $\begin{array}{l}\text { 16.Probabilidade de melhorar seus níveis de desempenho no } \\
\text { trabalho como resultados do uso das novas habilidades. }\end{array}$ & & & & & \\
\hline $\begin{array}{l}\text { 17.Capacidade de transmitir os conhecimentos adquiridos no } \\
\text { treinamento a outros servidores.. }\end{array}$ & & & & & \\
\hline $\begin{array}{l}\text { 18.Probabilidade de promover melhorias nas atividades } \\
\text { desenvolvidas pelo seu grupo de trabalho, com base nas } \\
\text { habilidades aprendidas no treinamento. }\end{array}$ & & & & & \\
\hline $\begin{array}{l}\text { 19.Contribuição do treinamento para sua integração com outros } \\
\text { servidores da sua área de atuação profissional. }\end{array}$ & & & & & \\
\hline $\begin{array}{l}\text { 20.Estímulo decorrente do treinamento para aplicar, no trabalho, } \\
\text { os conhecimentos e habilidades aprendidas. }\end{array}$ & & & & & \\
\hline
\end{tabular}




\begin{tabular}{|c|c|c|c|c|c|}
\hline \multicolumn{6}{|l|}{$\begin{array}{l}\text { 21.Intenção de aplicar no trabalho os conhecimentos adquiridos } \\
\text { no treinamento. }\end{array}$} \\
\hline SUPORTE ORGANIZACIONAL & Ruim & Insuficiente & Regular & Bom & Ótimo \\
\hline $\begin{array}{l}\text { 22.Probabilidade de dispor dos instrumentos, materiais, } \\
\text { suprimentos, equipamentos e demais recursos necessários ao } \\
\text { uso de novas habilidades. }\end{array}$ & & & & & \\
\hline 23.Oportunidades de praticar as novas habilidades no trabalho. & & & & & \\
\hline $\begin{array}{l}\text { 24.Probabilidade de encontrar, no seu ambiente de trabalho, um } \\
\text { clima propício ao uso das habilidades aprendidas no } \\
\text { treinamento. }\end{array}$ & & & & & \\
\hline \multicolumn{6}{|c|}{ AVALIAÇÃO DO INSTRUTOR } \\
\hline DESEMPENHO DIDÁTICO & Ruim & Insuficiente & Regular & Bom & Ótimo \\
\hline \multicolumn{6}{|l|}{ 25.Transmissão dos objetivos do treinamento. } \\
\hline \multicolumn{6}{|l|}{ 26.Sumarização e revisão do conteúdo ensinado. } \\
\hline \multicolumn{6}{|l|}{ 27.Nível de organização seqüencial do conteúdo do treinamento } \\
\hline \multicolumn{6}{|l|}{$\begin{array}{l}\text { 28. Nível de profundidade com que os temas e assuntos foram } \\
\text { abordados, tendo em vista o objetivo do treinamento. }\end{array}$} \\
\hline \multicolumn{6}{|l|}{ 29.Ritmo de apresentação dos tópicos. } \\
\hline \multicolumn{6}{|l|}{$\begin{array}{l}\text { 30.Uso de estratégias para motivar os alunos em relação aos } \\
\text { temas abordados no treinamento. }\end{array}$} \\
\hline \multicolumn{6}{|l|}{$\begin{array}{l}\text { 31.Qualidade da apresentação dos conteúdos e da } \\
\text { exemplificação. }\end{array}$} \\
\hline \multicolumn{6}{|l|}{$\begin{array}{l}\text { 32.Uso de estratégias instrucionais (exposições orais, discussões } \\
\text { em grupo e similares) em relação à apreensão do conteúdo. }\end{array}$} \\
\hline \multicolumn{6}{|l|}{$\begin{array}{l}\text { 33.Uso de recursos instrucionais (quadro de giz, quadro branco, } \\
\text { retroprojetor, etc.) em relação à apreensão do conteúdo. }\end{array}$} \\
\hline \multicolumn{6}{|l|}{ 34.Qualidade das avaliações de aprendizagem } \\
\hline DOMÍNIOS DO CONTEÚDO & Ruim & Insuficiente & Regular & Bom & Ótimo \\
\hline \multicolumn{6}{|l|}{ 35.Conhecimento dos temas abordados no treinamento. } \\
\hline \multicolumn{6}{|l|}{ 36.Segurança na transmissão dos conteúdos do treinamento. } \\
\hline ENTROSAMENTO COM OS TREINANDOS & Ruim & Insuficiente & Regular & Bom & Ótimo \\
\hline \multicolumn{6}{|l|}{ 37.Disposição para esclarecer dúvidas. } \\
\hline \multicolumn{6}{|l|}{$\begin{array}{l}\text { 38. Respeito às idéias manifestadas pelos alunos acerca dos } \\
\text { temas abordados no treinamento. }\end{array}$} \\
\hline 39.Estímulo dado aos alunos para manifestarem suas idéias. & & & & & \\
\hline
\end{tabular}

Comentários/Críticas/Sugestões: 
ANEXO B



\section{OBSERVAÇÕES E JUSTIFICATIVAS}

